OPEN ACCESS

Edited by:

Bruno Guigas,

Leiden University, Netherlands

Reviewed by:

Fawaz Alzaid,

Institut National de la Santé et de la

Recherche Médicale

(INSERM), France

Andrew James Murphy,

Baker Heart and Diabetes Institute, Australia

*Correspondence:

Michaela Tencerova

michaela.tencerova@fgu.cas.cz

Specialty section:

This article was submitted to

Bone Research,

a section of the journal

Frontiers in Endocrinology

Received: 16 January 2020

Accepted: 20 April 2020

Published: 12 May 2020

Citation:

Benova A and Tencerova M (2020) Obesity-Induced Changes in Bone

Marrow Homeostasis.

Front. Endocrinol. 11:294.

doi: 10.3389/fendo.2020.00294

\section{Obesity-Induced Changes in Bone Marrow Homeostasis}

\author{
Andrea Benova and Michaela Tencerova* \\ Molecular Physiology of Bone, Institute of Physiology of the Czech Academy of Sciences, Prague, Czechia
}

Obesity is characterized by low-grade inflammation, which is accompanied by increased accumulation of immune cells in peripheral tissues including adipose tissue (AT), skeletal muscle, liver and pancreas, thereby impairing their primary metabolic functions in the regulation of glucose homeostasis. Obesity has also shown to have a detrimental effect on bone homeostasis by altering bone marrow and hematopoietic stem cell differentiation and thus impairing bone integrity and immune cell properties. The origin of immune cells arises in the bone marrow, which has been shown to be affected with the obesogenic condition via increased cellularity and shifting differentiation and function of hematopoietic and bone marrow mesenchymal stem cells in favor of myeloid progenitors and increased bone marrow adiposity. These obesity-induced changes in the bone marrow microenvironment lead to dramatic bone marrow remodeling and compromising immune cell functions, which in turn affect systemic inflammatory conditions and regulation of whole-body metabolism. However, there is limited information on the inflammatory secretory factors creating the bone marrow microenvironment and how these factors changed during metabolic complications. This review summarizes recent findings on inflammatory and cellular changes in the bone marrow in relation to obesity and further discuss whether dietary intervention or physical activity may have beneficial effects on the bone marrow microenvironment and whole-body metabolism.

Keywords: bone marrow microenvironment, bone marrow mesenchymal stem cells, hematopoietic stem cells, immune responses, obesity, life-style interventions

\section{INTRODUCTION}

Bone marrow (BM) is a soft tissue localized inside of the bones and represents $\sim 5 \%$ of total body mass in healthy individuals (1). BM is primary recognized as a hematopoietic organ supporting the production of new blood cells (2). However, it has also a mechanical and immune function as it comprises bone marrow mesenchymal stem cells (BMSCs), important building blocks for bone formation, and hematopoietic stem cells (HSCs) responsible for producing several types of immune cells crucial for immune responses $(3,4)$. While BMSCs promote bone tissue regeneration by osteoblast differentiation and neo-vascularization thereby supporting growth of a new tissue, HSCs are quiescent cells $(5,6)$. However, in response to external cues HSCs can mobilize to the site of inflammation, A majority of HSCs reside in BM and $0.01 \%$ of them can migrate into circulation (7). Circulating HSCs in peripheral blood are attracted by several biochemical factors and cytokines including SCF, CXCL12, or IL-8 $(8,9)$. 
The initiation of hematopoiesis starts in the fetal liver, where HSCs proliferate and then migrate to BM. Later during adulthood HSCs continuously migrate from BM to peripheral blood, which maintains steady hematopoiesis (10). In the process of HSC migration from BM, stem cells leave proliferative niches and migrate to more oxygenated and vascularized regions in $\mathrm{BM}$ (11). In cases of stress, injury or pharmacological intervention, alterations in HSC niche formation and interaction with BMSCs lead to HSC mobilization and egress. These processes are affected by the metabolic status of an organism, which is altered by caloric restriction, obesity and type 2 diabetes (12). However, it is not well-documented how the composition of BM, interaction between HSCs and BMSCs, and the inflammatory status in this organ are affected in metabolic complications.

Thus, the purpose of this review is to give an overview of the latest literature on inflammatory changes in the BM microenvironment in relation to bone homeostasis. Also, we will discuss how BM composition and secretory function change in different metabolic states and whether dietary intervention or physical activity may have beneficial effects on the BM microenvironment and whole-body metabolism.

\section{BONE MARROW AS AN IMMUNE AND ENDOCRINE ORGAN}

$\mathrm{BM}$ is a heterogeneous immune organ, which consists of various cell types with different immune functions, including HSCs (myeloid and lymphoid precursors), which are important for immune cell production and BMSCs with immunosuppressive properties $(3,4,13)$. It has been reported that $8-20 \%$ of $\mathrm{BM}$ mononuclear cells belong to

Abbreviations: AT, Adipose tissue; BATF, Basic leucine zipper transcription factor, ATF-like; BM, Bone marrow; BMI1, B lymphoma Mo-MLV insertion region 1 homolog; BMP, Bone morphogenic protein; BMSC, Bone marrow mesenchymal stem cell; C/EBP, CAAT enhancer binding protein; CD25 (CD80, CD86, CD40, CD69), Cluster of differentiation 25, 80, 86, 40, 69; Cdc42, Cell division control protein 42 homolog; CTSK, Cathepsin K; CTHRC1, Collagen triple helix repeat containing 1; CXCL12, C-X-C motif chemokine 12; Del-1, Developmental endothelial locus 1; DNMT1, DNA methyltransferase 1; FO, Fish oil; GATA 13- GATA-binding protein 1-3; G-CSF, Granulocyte-colony stimulating factor; GFI1- Zinc-finger protein GFI1; H4K15ac, Acetylation on lysin 16 of histone 4; HGF, Hepatocyte growth factor; HSC, Hematopoietic stem cell; IDO, Indoleamine 2,3-dioxygenase; IFN $\alpha$, Interferon alpha; IFN $\beta$, Interferon beta; IFN $\gamma$, Interferon gama; IGF-1, Insulin-like growth factor 1; IL-1 (IL-1 $\beta$, IL-2, IL-4, IL-6, IL-7, IL-8, IL-15, IL-21), Interleukin 1-21; LCN2, Lipocalin 2; LepR, Leptin receptor; LFA-1, Lymphocyte function-associated antigen 1; LIF, Leukemia inhibitory factor; MCP1, Monocyte chemoattractant protein 1; MIF, Macrophage stimulating factor; M-CSF, Macrophage colony-stimulating factor; NKT, Natural killer cell; OPG, Osteoprotegerin; OPN, Osteopontin; $\mathrm{PGE}_{2}$, Prostaglandin $\mathrm{E}_{2}$; PPAR $\gamma$, Peroxisome proliferator-activated receptor gama; PUFA- Poly unsaturated fatty acid; RANKL, Receptor activator of nuclear factor- $\mathrm{\beta} \beta$ ligand; RUNX2, Runtrelated transcriptional factor 2; S100A8/A9, Neutrophil-derived S100 calciumbinding proteins A8/A9; SCF, Stem cell factor; SDF-1, Stromal cell-derived factor 1 ; sFRP1, secreted Frizzled-related protein 1 ; TGF- $\beta_{1}$, Transforming growth factor beta 1; TLR4, Toll-like receptor 4; TN-C, Tenascine-C; TNF $\alpha$, Tumor necrosis factor alpha; TNF $\beta$, Tumor necrosis factor beta; TRAP, Tartrate-resistant acid phosphatase; Treg, Regulatory T cell; VLA-4 (VLA-5, VLA-7), Very late antigen 4, 5, 7; WBV, Whole body vibration; Zfp432, Zinc finger protein 432; Zfp521- Zinc finger protein 521. lymphocyte lineage ( $\mathrm{T}$ cells, B cells, Tregs) $(14,15)$ and approximately $1 \%$ represent plasma cells contributing to antibody production (16). Also located in the BM are natural killer T cells (NKT) (cca 0.4-4\%) (17), dendritic cells (1-2\%) (18), myeloid progenitor cells (giving rise to osteoclasts), megakaryocytes important for platelets (thrombocytes) production via thrombopoietin (1\%) (19), neutrophils (8$15 \%)$, eosinophils (0.5-2\%), and basophils (0.01-2\%) (Figure 1). Importantly, BM represents a major reservoir of neutrophils and provides migration of these cells into circulation as a first host defense in response to infection and stress (20). Neutrophils are also cleared in BM; once they are senescent, they are phagocytosed by stromal BM macrophages (21). Thus, BM is a home of immune and progenitor cells, whose composition can be changed with age, metabolic status, or inflammatory condition.

Further, BM is well-vascularized with blood vessels and sinusoids, which create a barrier between BM and peripheral circulation $(22,23)$. This microvasculature allows a release of proliferating progenitor cells and secreted molecules from $\mathrm{BM}$ into blood stream in order to reach peripheral tissues depends on the stimulatory signals or physiological condition, which modulate a local microenvironment of the target tissue (24).

Early in life, many bones contain red BM with a high hematopoietic activity, which decrease and turn red BM into yellow "fatty" BM with aging (25). In adults, there are few bones with red BM (e.g., sternum, vertebrae, ribs, or pelvic bone) contributing to hematopoiesis (26). Thus, the bone homeostasis at different body sites is affected by BM composition of HSCs and BMSCs, which contribute to bone integrity, and mechanical and immune properties $(4,27)$. The crosstalk between these cells activate several processes, including proliferation, migration, and differentiation of stem cells, which are accompanied with production of various bioactive molecules creating the BM microenvironment $(3,4,25)$. The maintenance of this microenvironment is important for healthy cell development, immune system function and metabolism.

\section{INTRINSIC REGULATORS OF HEMATOPOIETIC STEM CELL AND BONE MARROW MESENCHYMAL STEM CELL DIFFERENTIATION}

HSCs and BMSCs represent multipotent stem cells, which can differentiate into different cell types based on the regulation via intrinsic (e.g., transcription factors and cofactors, posttranscriptional and posttranslational modifications) and extrinsic factors (e.g., secretory molecules, BM microenvironment, metabolic cues) (28). HSC differentiation is coordinated by transcription factors such as c-Myc, PU.1/Spi1, GATA1-3, TNFß, EGR1, BMI1, Gfi1, FoxO3, and others (29). c-Myc, for example, regulates the balance between HSC 


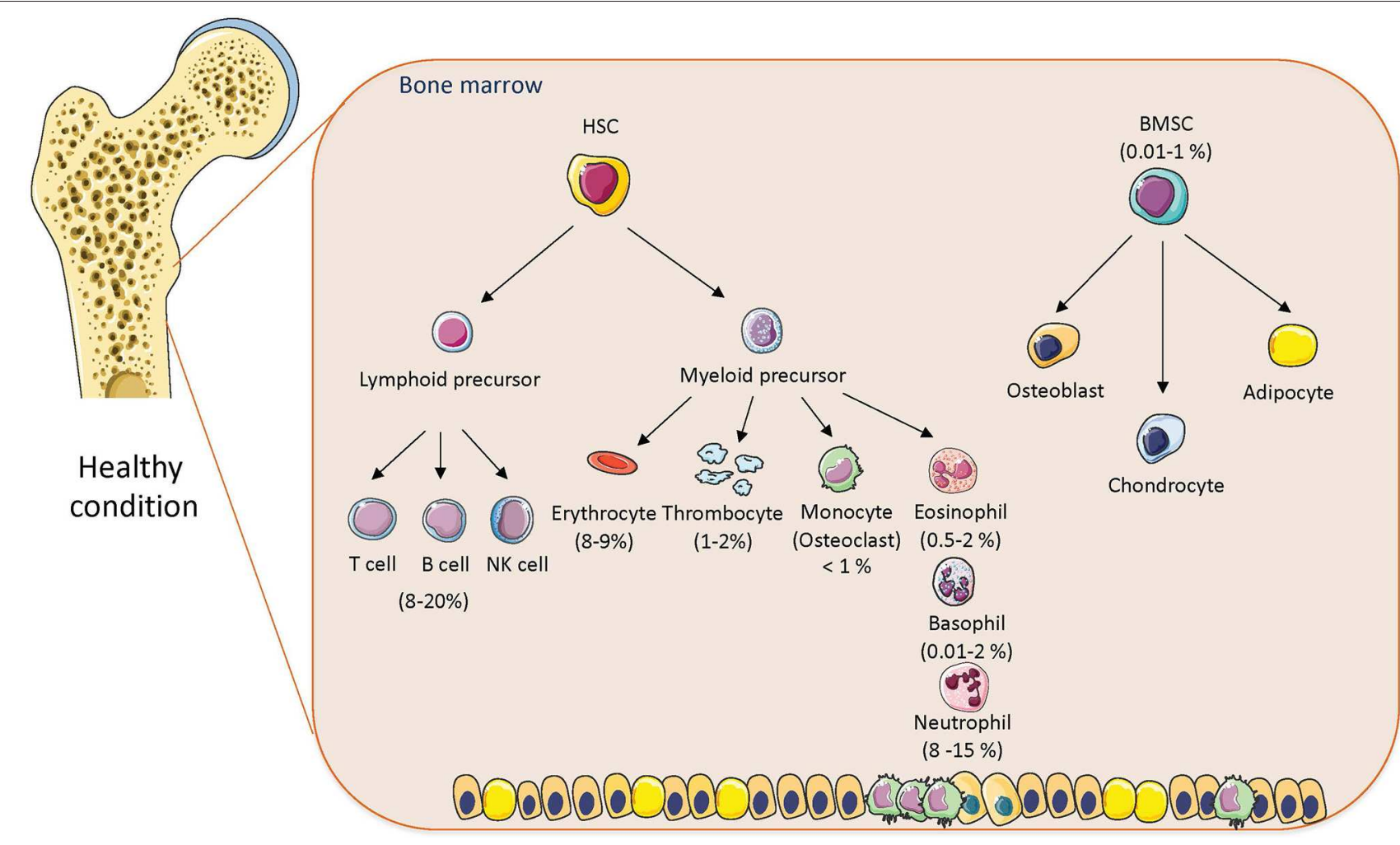

FIGURE 1 | The cellular composition of bone marrow in healthy conditions. The composition of hematopoietic stem cells (HSCs) and bone marrow mesenchymal stem cells (BMSCs) with percentage in bone marrow in normal physiological condition. Cell animations were adapted from SERVIER Medical Art; https://smart.servier. com to create the figure.

self-renewal and differentiation (30). PU.1/Spi-1 is involved in myeloid lineage determination via regulation of target genes, including granulocyte colony-stimulating factor receptor (31), granulocyte-macrophage colony-stimulating factor receptor (32) and macrophage colony-stimulating factor receptor (33). Some studies showed that PU.1/Spi-1 expression can direct stem cell differentiation to myeloid lineage if Notch signaling is reduced [reviewed in Rothenberg et al. (34)]. Another regulatory molecule of HSC differentiation is Ikaros, which displays a crucial function as a transcription activator promoting lymphocyte differentiation. Impairment of this protein leads to hypoplasia, absence of secondary lymphoid organs or absence of B- and T- cell precursors (35). Basic leucine zipper transcription factor, ATF-like (BATF) is an important factor promoting lymphoid lineage differentiation (36), while TNF $\beta$ serves as a negative regulator of HSC selfrenewal (37). Further, the HSC cell fate determination is regulated by GATA1-3, zinc finger transcription factors, which coordinate development of diverse hematopoietic lineages (38), and B lymphoma Mo-MLV insertion region 1 homolog (BMI1), which is important for the multilineage potential of HSCs and their replating capacity $(39,40)$. Lee et al. recently identified a role of a transcriptional repressor, known as Gfil in the regulation of HSC quiescence and self-renewal, which is modulated by metabolic status (i.e., upregulated with obesity and decreased with weight loss) (41). Besides transcriptional regulation, HSC renewal and differentiation are under control of posttranslational modifications, including DNA methylation, acetylation, or ubiquitination, which can be modulated by aging or metabolic diseases (42). Recent findings documented that increases in $\mathrm{H} 4 \mathrm{~K} 16 \mathrm{Ac}$ levels results in inhibition of $\mathrm{Cdc} 42$, which leads to restoration of the $B$ cell lineage output in aged HSCs (43). Further, G9a/GLP methyltransferase is responsible for increased levels of $\mathrm{H} 3 \mathrm{~K} 9 \mathrm{me} 2$ pattern associated with HSC lineage commitment. On the other hand, inhibition of G9a/GLP decrease differential potential of stem cells and improves HSC maintenance (44). Additionally, methylation by DNA methyltransferase 1 (DNMT1) permits efficient hematopoietic differentiation (45). All above-mentioned transcription factors and posttranslational modifications are only part of the HSC regulatory network, which shows together the complexity of stem cell differentiation process.

Differentiation of BMSCs toward osteoblasts and adipocytes is regulated by specific transcription factors: Runt-related transcription factor 2 (Runx2) (46), osterix (47), GATA2 (48, 49) (responsible for osteoblast lineage determination), and 
TABLE 1 | Transcription factors and determinants of HSC and BMSC differentiation.

\begin{tabular}{|c|c|c|c|c|}
\hline $\begin{array}{l}\text { Intrinsic } \\
\text { regulators }\end{array}$ & Cell type & Function & Obesity & Life-style interventions \\
\hline BATF & HSC & Transcription factor regulating lymphoid differentiation (36) & - & - \\
\hline BMl1 & HSC & Transcription factor regulating multilineage potential of HSCs $(39,40)$ & - & - \\
\hline TNF $\beta$ & HSC & Negative regulator of HSC self-renewal (37) & - & - \\
\hline c-Myc & HSC & $\begin{array}{l}\text { Transcription factor regulating balance between HSC self-renewal and } \\
\text { differentiation (15545632) }\end{array}$ & - & - \\
\hline Pu.1/Spi-1 & HSC & Transcription factor regulating myeloid lineage differentiation (31) & $\uparrow(54,55)$ & - \\
\hline Ikaros & HSC & Transcription activator of lymphoid differentiation (35) & - & - \\
\hline Notch & HSC & $\begin{array}{l}\text { Signaling molecule enhancing self-renewal and regenerative capacity of } \\
\text { HSCs (56) }\end{array}$ & - & - \\
\hline GATA1-3 & HSC & Transcription factors regulating HSC lineage determination (38) & $\uparrow$ GATA 3 (57) & - \\
\hline Gfi1 & HSC & Transcription factor regulating HSC quiescence and self-renewal (58) & $\uparrow(59)$ & $\downarrow$ Weight loss (59) \\
\hline DNMT1 & BMSC & $\begin{array}{l}\text { DNA methyltransferase promoting HSC differentiation to myeloid } \\
\text { lineage (45) }\end{array}$ & - & - \\
\hline Runx2 & BMSC & Transcription factor promoting osteoblast differentiation (46) & $=(60)$ & $\uparrow$ Vibration (61) \\
\hline Osterix & BMSC & Transcription factor promoting osteoblast differentiation (47) & $\downarrow(62)$ & $\begin{array}{l}\downarrow \text { Low magnitude high } \\
\text { frequency vibration (63) }\end{array}$ \\
\hline PPAR $\gamma$ & BMSC & Transcription factor regulating adipogenesis (50) & $\uparrow(60)$ & $\begin{array}{l}\uparrow \text { Low magnitude height } \\
\text { frequency vibration (64) }\end{array}$ \\
\hline GATA2 & BMSC & Transcription factor regulating adipogenesis and osteogenesis $(48,49)$ & - & - \\
\hline C/EBP & BMSC & Transcription factor regulating adipogenesis (4) & $\uparrow(65)$ & $\begin{array}{l}\uparrow \text { Low magnitude height } \\
\text { frequency vibration (64) }\end{array}$ \\
\hline TGF- $\beta_{1}$ & BMSC & Negative regulator of adipogenesis (4) & $\downarrow(66)$ & - \\
\hline BMP-2 & BMSC & Positive regulator of osteoblast differentiation (51) & $\downarrow(67)$ & $=$ Calorie restriction (68) \\
\hline Zfp521 & BMSC & Regulator supporting osteoblast differentiation (53) & - & - \\
\hline
\end{tabular}

peroxisome proliferated-activated receptor gamma (PPAR $\gamma)$ (50), CAAT enhancer binding protein (C/EBP) family (4) (responsible for adipocyte lineage determination). The activation of these transcription factors can be controlled by Wnt signaling, transforming growth factor $\beta_{1}$ (TGF- $\beta_{1}$ ) and bone morphogenic proteins (BMPs) [reviewed in Tencerova and Kassem (4)]. The regulation of BMSC differentiation is also accompanied by epigenetic modifications. For example, histone deacetylation in genes involved in transcriptional regulation, cellular survival, growth and proliferation of BMSCs. Increased acetylation during osteoblast differentiation results in increased expression of Runx2, BMP-2, osterix and osteopontin (OPN), which are important for osteoblast maturation $(51,52)$. A recent study by Addison et al. identified Zfp521 as a key regulator of lineage specification in progenitor cells, regulating BMP-induced MSC differentiation coupled with histone modification at Zfp423 promoter (53).

These data demonstrate that HSC and BMSC differentiation are complex processes under the control of specific transcription factors, whose activity is further epigenetically modulated. These intrinsic factors contribute to the regulation of the BM homeostasis and are changed by obesity and dietary interventions. Table 1 summarizes key factors and determinants regulating HSC and BMSC differentiation and associated signaling pathways.

\section{SECRETORY FACTORS OF BONE MARROW MESENCHYMAL STEM CELLS AFFECTING BONE HOMEOSTASIS AND IMMUNE CELL PROPERTIES}

BMSCs represent around $0.01-0.1 \%$ of total BM cells in adults and are capable of differentiating into different cell types such as osteoblasts (bone formation), adipocytes (adipose tissue formation) or chondrocytes (cartilage formation), all of which are important for maintaining of bone homeostasis $(4,13)$. BMSCs are also known for their immunosuppressive properties as they express human leucocyte antigen (HLA) class I and costimulatory molecules CD80, CD86, or CD40 important for regulation of $\mathrm{T}$ cell proliferation and activation $(69,70)$. Recent findings suggest that BMSCs mediate their immunoregulatory function via cell-cell interactions and secretion of soluble molecules $(70,71)$. The BMSC secretory profile of prostaglandin $\mathrm{E}_{2} \quad\left(\mathrm{PGE}_{2}\right)$, hepatocyte growth factor (HGF), transforming growth factor (TGF) $-\beta_{1}$ and indoleamine 2,3-dioxygenase (IDO) show profound immunosuppressive properties inhibiting $\mathrm{T}$ cell activation and proliferation without affecting expression of early activation markers such as CD25 and CD69 (72). Indeed, BMSCs can modulate function of several immune cells without being recognized by immune cells. BMSCs inhibit proliferation and antibody production of $\mathrm{B}$ cells (73), differentiation of 
TABLE 2 | Secretory factors of BMSCs contributing to BM microenvironment and bone homeostasis.

\begin{tabular}{|c|c|c|c|}
\hline $\begin{array}{l}\text { Secretory } \\
\text { factors }\end{array}$ & Function & Obesity & $\begin{array}{l}\text { Life-style } \\
\text { interventions }\end{array}$ \\
\hline $\mathrm{PGE}_{2}$ & $\begin{array}{l}\text { Anti-inflammatory, inhibition of T cell } \\
\text { proliferation (72) }\end{array}$ & $\downarrow(59)$ & $\begin{array}{l}\text { Omega } 3 \text { dietary } \\
\text { intervention } \downarrow \text { (82) }\end{array}$ \\
\hline HGF & $\begin{array}{l}\text { Anti-inflammatory, inhibition of T cell } \\
\text { proliferation (72) }\end{array}$ & - & - \\
\hline TGF $\beta$ & $\begin{array}{l}\text { Anti-inflammatory, inhibition of T cell } \\
\text { proliferation (72) }\end{array}$ & $\downarrow(66)$ & - \\
\hline |L-7 & B cell development (83) & $\downarrow(84)$ & - \\
\hline IL-15 & T cell homeostasis (85) & $\downarrow(86)$ & - \\
\hline IL-21 & NKT cells maturation (87) & - & - \\
\hline TNF $\alpha$ & HSC proliferation and activation (88) & $\downarrow(60), \uparrow(89)$ & - \\
\hline CXCL12/SDF-1 & Stem cell migration $(90,91)$ & $\downarrow(92)$ & $\begin{array}{l}\uparrow \text { Exercise, caloric } \\
\text { restriction }(68,93)\end{array}$ \\
\hline G-CSF & Myelopoiesis (100) & $\uparrow-(101,102)$ & $\begin{array}{l}\uparrow \text { Sleeve gastrectomy } \\
(100)\end{array}$ \\
\hline RANKL & Osteoclast differentiation (103) & $\uparrow(104)$ & $=$ Exercise $(105)$ \\
\hline OPG & Osteoclast differentiation (103) & $\downarrow(104)$ & $=$ Exercise (105) \\
\hline LCN2 & $\begin{array}{l}\text { HSC proliferation, inhibition of senescence } \\
\text { (106) }\end{array}$ & $\downarrow(60)$ & - \\
\hline
\end{tabular}

HSC progenitors into dendritic cells (74), and they promote anti-inflammatory cytokine production of myeloid cells while inhibiting the cytotoxic activity of NKT cells (75-77). Although there is limited information on the exact mechanism of BMSC immunoregulation in relation to immune cell interaction, they represent an important tool in stem cell therapy. BMSCs have been used in several clinical trials for tissue regeneration and healing (78-81).

The secretory profile of BMSCs may differ depend on developmental, immune or metabolic challenges they are exposed to. A brief overview of BMSC secretory factors is listed in Table 2, describing their functions and changes in metabolic complications and life-style interventions. BMSCs secrete IL7 , which is important for early B cell development $(83,84)$, IL-15 for $\mathrm{T}$ cell homeostasis (85) and IL-21 for maturation of NKT cells (87). Further, expression of CXCL12/SDF-1 mediates the interaction of BMSCs with BM endothelial cells in order to contribute to the maturation of megakaryocytes and thrombopoiesis. SDF-1 also initiates trans-endothelial migration of BMSCs in homing process via activation of integrins (LFA-1, VLA-4, and VLA-5) (90, 91). Moreover, BMSC secretory products, including leukemia inhibitory factor (LIF), macrophage stimulating factor (MIF), granulocyte-colony stimulating factor (G-CSF), OPN, IL-6, tumor necrosis alpha $(\mathrm{TNF} \alpha)$ affect immune cell behavior $(102,107,108)$. Costa et al. showed that osteoblast-derived lipocalin 2 (LCN2), with its anti-senescent function, regulates HSC progenitors and their proliferation capacity (106). Functional studies indicate that thrombopoietin and angiopoietin secreted by osteoblasts promote HSC quiescence $(94,98,109)$, while CXCL12 regulates
HSC migration in $\mathrm{BM}(110,111)$. In addition, osteoblasts may regulate the activity of osteoclasts (derived from myeloid precursors in $\mathrm{BM}$ ) in order to attract them to the site of resorption, thereby maintaining bone homeostasis (112). Osteoblasts produce receptor activator of nuclear factor- $\kappa \beta$ ligand (RANKL) and osteoprotegerin (OPG), two critical factors in osteoclast differentiation and activation (103). Osteocytes (mature osteoblasts) modulate myelopoiesis via activation of Gs $\alpha$-dependent signaling, which regulates secretion of G-CSF $(100,113)$. These data point out the importance of maintaining $\mathrm{BM}$ homeostasis, which is based on the molecular interactions among different cell types present in BM. And changes in local BM microenvironment induced by metabolic status of organism may shift this balance in favor of action of specific progenitors, which disrupt the priming of immune cell progenitors arising in $\mathrm{BM}$ in their function when they reach circulation.

\section{SECRETORY FACTORS OF HEMATOPOIETIC STEM CELLS AFFECTING BONE HOMEOSTASIS AND IMMUNE CELL PROPERTIES}

Multipotent HSCs represent another cellular component of $\mathrm{BM}$, which are recognized as the ancestors of blood cells (114116). Traditionally, HSCs differentiate into myeloid lineage (e.g., erythrocytes, granulocytes, macrophages, monocytes, and platelets) or lymphoid lineage [e.g., B lymphocytes, T lymphocytes, and natural killer (NK) cells] (117). While myeloid cells mature in the BM, human lymphoid cells must 
TABLE 3 | Secretory factors of HSCs contributing to BM microenvironment and bone homeostasis.

\begin{tabular}{|c|c|c|c|}
\hline $\begin{array}{l}\text { Secretory } \\
\text { factors }\end{array}$ & Function & Obesity & $\begin{array}{l}\text { Life-style } \\
\text { interventions }\end{array}$ \\
\hline IL-1 $\beta$ & HSC activation (128) & $\downarrow(60)$ & $\begin{array}{l}\downarrow \text { Dietary restriction- } \\
\text { reduced intake of } \\
\text { amino acids (129) }\end{array}$ \\
\hline MCP1 & HSC activation (128) & $\downarrow(60)$ & - \\
\hline $\mathrm{TNF} \alpha$ & HSC activation $(128,130)$ & $=(60)$ & - \\
\hline Wnt10b & Bone formation (131) & $\downarrow(132)$ & - \\
\hline CXCL16 & Osteoblast migration (133) & - & - \\
\hline TRAP & Osteoclast activation (134) & $\begin{array}{l}=(60) \\
\uparrow(135)\end{array}$ & $\begin{array}{l}\downarrow \text { Caloric restriction } \\
(136)\end{array}$ \\
\hline LIF & Osteoblast migration (133) & - & - \\
\hline CTSK & Collagen degradation (137) & - & - \\
\hline CTHRC1 & Bone formation (138) & - & - \\
\hline Del-1 & $\begin{array}{l}\text { HSC proliferation and } \\
\text { differentiation (139) }\end{array}$ & - & - \\
\hline TN-C & $\begin{array}{l}\text { Bone remodeling and bone } \\
\text { renewal (140) }\end{array}$ & $\uparrow(141)$ & - \\
\hline
\end{tabular}

migrate to other lymphoid organs (e.g., thymus) in order to complete their maturation. In most of the experimental models, multipotency of HSCs is coupled with self-renewal abilities (118). HSCs together with endothelial cells (119), LepR ${ }^{+}$ stromal cells (120), megakaryocytes (121), sympathetic nerves, non-myelinating Schwan cells (122) and secreted bioactive molecules (123-126) create a dynamic BM microenvironment (127). Table 3 summarizes HSC secretory factors contributing to $\mathrm{BM}$ homeostasis along with their functions and changes in metabolic complications and life-style interventions. The BM microenvironment mediates signals for HSCs to differentiate into particular cell type in response to infection or blood cell destruction $(142,143)$. Interactions between HSCs and BMSCs are tightly interlinked by secreted signals and regulatory factors affecting the quiescence, self-renewal or mobilization of stem cells. HSCs are capable of receiving and producing signals that directly dialogue with the immune system. A recent study by Mitroulis et al. identified developmental endothelial locus-1 (Del-1) glycoprotein secreted by several components of HSC niche such as endothelial cells, reticular cells as a regulator of long-term HSC proliferation and differentiation toward the myeloid lineage (139). Another protein expressed in extracellular matrix of $\mathrm{BM}$ is tenascine-C (TN-C), important for active bone remodeling and HSC renewal in the endosteal region in conditions of hematopoietic stress $(140,144,145)$.

In the context of inflammation, HSCs are recognized as primary responders to infection, and the secretion of proinflammatory cytokines during infection is important for HSC regulation. This cascade of pro-inflammatory cytokines and signaling molecules includes IL-1, IL-2, IL-8, TLR4 (146), TNF $\alpha$ (147), IFN $\alpha, \beta$, and $\gamma$ (148) to activate T cells, NKT, and IL4 and IL-6 to activate B cells [reviewed in King and Goodell (149)]. These cytokines are required for the maintenance of the appropriate proliferation and differentiation of HSCs in the steady-state and stress-induced condition.
Another cell type derived from the myeloid lineage are osteoclasts ("bone macrophages"), which are key players in process of bone resorption. Osteoclasts are specialized multinucleated cells derived from monocyte fusion containing from 2 to 12 nuclei per cell (150). The process of osteoclast differentiation is regulated via main activators of osteoclast formation, RANKL and M-CSF. In addition, RANKL promotes osteoclast resorption activity (151). In healthy conditions, osteoclasts play an important role in replacing of old or damaged bone matrix (bone resorption), which is followed by osteoblasts forming a new mineralized bone matrix (bone formation). This renewal process of bone matrix is also known as bone remodeling, which is energetically demanding (152). During this process, osteoclasts communicate with osteoblasts through cytokines such as TGF- $\beta$ and IGF-1, which promote migration of BMSCs to newly resorbed tissue $(153,154)$. TGF- $\beta$ can also induce expression of CXCL16, LIF, and Wnt10b by osteoclasts, which induce mineralization and recruitment of osteoclasts to osteoblasts $(131,133)$. Activated osteoclasts further produce secreted factors supporting their resorption activity, including cathepsin K (CTSK), sphingosine-1-phospate (137), tartrateresistant acid phosphatase (TRAP) (134). CTSK is cysteine protease secreted by osteoclasts with an essential function in degradation of matrix collagen and activation of TRAP (155, 156). Mutation in CTSK leads to pycnodysostosis, rare autosomal recessive skeletal dysplasia, during which osteoclasts function is defected. Animal models with this deficiency showed reduced bone resorption, which together with normal or increased bone formation led to osteopetrotic phenotype (137). TRAP is a phosphatase expressed by osteoclasts and macrophages participating in skeletal development, collagen synthesis, and degradation or mineralization of bone matrix (134). Another molecule secreted by osteoclasts is collagen triple helix repeat containing 1 (CTHRC1), which serves as a positive regulator of osteoblastic bone formation $(138,157)$. These data provide further evidence that HSCs are capable of producing several inflammatory molecules, which contribute to creation of the $\mathrm{BM}$ microenvironment. Importantly, HSC differentiation in process of building active immune cells is under control of several bioactive molecules and signaling pathways, which need to be tightly regulated in response to metabolic or inflammatory stressors.

\section{OBESITY-INDUCED CHANGES IN BONE MARROW}

Obesity is characterized by low-grade inflammation, challenging the immune cell responses in peripheral tissues. Further, the obesogenic condition increases BM cellularity 20-30\% (101), changes BM composition of HSC and BMSC subpopulations and affects their differentiation capacity and increases white and red blood cell counts (Table 4) $(96,158,164,165,172)$. Conditions associated with metabolic dysregulations, including hyperglycemia and hypercholesterolemia, have been linked to hematopoietic disruption and particularly to myeloid skewing $(84,165,183)$. 
TABLE 4 | The changes in cellular composition of hematopoietic stem cells and bone marrow mesenchymal stem cells in bone marrow in obesity, exercise and dietary interventions.

\begin{tabular}{|c|c|c|c|}
\hline Cell type & Obesity & Exercise & $\begin{array}{l}\text { Dietary } \\
\text { intervention }\end{array}$ \\
\hline Erythrocytes & $\uparrow(158)$ & $\downarrow(159)$ & $\begin{array}{l}\uparrow(160) \\
\downarrow(161)\end{array}$ \\
\hline Lymphocytes & $\downarrow(162)$ & $\uparrow(162,163)$ & $\uparrow(160)$ \\
\hline $\begin{array}{l}\text { Monocytes } \\
\text { (Osteoclasts) }\end{array}$ & $\uparrow(164-166)$ & $\downarrow(167)$ & $\downarrow(167)$ \\
\hline Eosinophils & $\downarrow(168,169)$ & - & $\uparrow(169)$ \\
\hline Basophils & $\uparrow(170)$ & $\uparrow(171)$ & - \\
\hline Neutrophils & $\begin{array}{l}\uparrow(164,165, \\
172)\end{array}$ & $\downarrow(173,174)$ & $\downarrow(174)$ \\
\hline Thrombocytes & $\uparrow(96)$ & - & $\downarrow(97)$ \\
\hline Chondrocytes & $\downarrow(175,176)$ & $\uparrow(177)$ & $\uparrow(178)$ \\
\hline Osteoblasts & $\downarrow(60)$ & $\uparrow(162,163)$ & $\uparrow(179,180)$ \\
\hline $\begin{array}{l}\text { Bone marrow } \\
\text { adipocytes }\end{array}$ & $\uparrow(60)$ & $\downarrow(162,163)$ & $\downarrow(181,182)$ \\
\hline
\end{tabular}

Hyperglycemia drives myelopoiesis and activation of neutrophils in the BM of obese mice $(164,165)$. Moreover, HFD-induced changes in bone architecture and immune cell homeostasis showed bone loss and a shift of HSC differentiation in myeloid over lymphoid progenitors $(60,162,184)$. Further, morbid obesity elevated neutrophils in circulation and primed their immune function and metabolic activity, suggesting a higher inflammatory response in obesity-related diseases associated with impaired whole-body glucose metabolism (172). Another study by Kraakman et al. demonstrated that an obesogenic condition coupled with high glucose levels promotes increased thrombopoiesis via interaction of neutrophil-derived S100 calcium-binding proteins A8/A9 (S100A8/A9) and thrombopoietin in hepatocytes, which in turn leads to megakaryocyte activation and thrombocyte maturation in BM (96). Also, eosinophils with their antiinflammatory activity have been shown to be affected by obesity, evidenced by decreased accumulation in AT and enhanced trafficking from $\mathrm{BM}$ to lung during allergic asthma (168, 185). Obesity-induced changes have been attributed also to basophils, which participate in lung inflammation and allergic reaction associated with metabolic complications (170).

It has been shown that differentiation capacity of BMSCs is changed by obesity in favor of increased adipocyte differentiation and impaired osteoblast and chondrocyte differentiation, which contributes to impairment of bone homeostasis and production of secretory factors affecting the function of neighboring cells in BM $(60,175,176,186)$. Liu et al. (54) recently reported an impairment of BMSC mobilization and selective migration of specific immune cells from BM into circulation in obesity. Further, Ferraro et al. showed a negative effect of diabetes on HSC mobilization capacity by changing the BM microenvironment (92). Not only proportion of immune cells in BM, but also secretion of inflammatory cytokines is modified by obesity (see some examples in Table 2). For instance IL15 with its anti-obesity effect, TGF- $\beta$ and IL-7 with their immunosuppressive properties are decreased with obesity in $\operatorname{BM}(66,84,86)$.

Previous studies in rodents under HFD condition have demonstrated increased pro-inflammatory BM microenvironment (e.g., TNF $\alpha$, IL- 6 , and IL-1 $\beta$ ) measured in BM or bone lysates $(89,104,187)$. Our recent publications have reported that obesity does not induce increased inflammatory responses in BMSCs and HSCs of HFD mice or obese individuals compared to lean, which is accompanied with no change or decrease in osteoclast resorption activity $(60,188)$. This finding was also found in the study by Trotter et al., showing no changes in the mRNA levels of inflammatory markers in BM of HFD mice compared to lean (101). Further, obesity was identified as a negative factor of bone homeostasis in relation to osteoclast formation $(104,166,189)$. Halade et al., using 12 months old female mice fed with $10 \%$ corn oil as a model of age-associated obesity, showed that increased adiposity enhances pro-inflammatory cytokine production (e.g., IL-1 $\beta$, IL-6, and $\mathrm{TNF} \alpha$ ) and was associated with a higher differentiation of osteoclasts (104, 190). Another animal study using 5 weeks old male mice found higher rates of osteoclast precursors, as well as elevated osteoclast formation, bone resorption activity and increased expression of RANKL, TNF $\alpha$, and TRAP (166). In addition, acute exposure to dietary fatty acids increased osteoclastogenic activity in circulating monocytes and increased secretion of cytokines (191). However, this study did not investigate the osteoclast in $\mathrm{BM}$ and their resorption activity. In our animal study using a HFD model $(60 \%$ calories from fat) in 12 weeks old C57BL/6 male mice, we did not observe any significant changes in osteoclast activity or number (60). In clinical study (188) examining obese subjects, we found decreased bone resorption and bone formation activity, suggesting a slowing of bone turnover. The discrepancies between studies may be explained by using different animal models, length/composition of the diet, or different source of bone cells for measurement of inflammatory condition in BM.

In terms of HSC secreted molecules (e.g., CXCL16, CTSK, Del-1, LIF, or CTHRC1), which play an important role in bone homeostasis and metabolism (Table 3), there is very limited information about expression changes in the BM during obesity. Thus, these observations suggest that further studies are needed in order to investigate the inflammatory status of BM cells and their microenvironment in obesity in relation to bone and whole-body metabolism.

However, it raises further questions whether obesogenic condition activates immune cells in BM or immune cells need to migrate through the circulation into the target tissue, i.e., adipose tissue (AT), skeletal muscle, liver to activate their inflammatory status. This would suggest that BM is a primary site of immune cell production and plays an important role in immune cell mobilization into circulation, whereby these cells are directed to traffic into the sites of inflammation. 


\section{LIFE-STYLE INTERVENTIONS: DIETARY AND PHYSICAL ACTIVITY INTERVENTIONS IMPROVE OBESITY-INDUCED CHANGES IN BONE MARROW HOMEOSTASIS}

In obesity and type 2 diabetes, several approaches have been applied to treat or prevent the detrimental effects of metabolic complications. These include physical activity, as well as dietary or pharmacological treatment. As a lot of investigations have been focused on the metabolic and inflammatory improvements in peripheral tissues, there is limited information on these parameters in relation to BM homeostasis (Tables 1-4).

Dietary supplementation with long-chain n-3 ( $\omega-3)$ PUFAs, supplied as fish oil (FO), which is known for its antiinflammatory effects, demonstrated to be beneficial for skeletal health, as evidenced by increased osteogenesis and decreased osteoclastogenesis $(179,180)$. A recent study by Cao et al. (192) reported that 6 months of a FO diet increased bone density and microstructure. However, they did not investigate bone adiposity or inflammatory responses in BM in these conditions.

Exercise also showed a positive effect on bone homeostasis. In rodents and humans, exercise has been shown to increase bone density, decrease bone adiposity, and improve chondrogenesis in HFD mice and humans $(177,193,194)$. Further, increased physical activity has been shown to promote HSC proliferation and differentiation and modulate immune cell composition in circulation (159, 171, 173, 195-197) (Table 3). An additional effect of exercise on the bone is increased mechanical stress for skeletal system induced by whole body vibration (WBV), which has been shown to improve bone density by reducing bone marrow adiposity in mice and humans and restoring lymphopoiesis (increased number of B cells). WBV also showed an effect on immune cells in circulation and induced lower infiltration in AT $(162,163)$. A key strategy to prevent obesity and its complications, including bone health, is a combination of exercise and a well-balanced diet. A study by Garbiax et al. using 11 months old male rats showed that exercise along with a caloric restricted diet (low fat and low sucrose) decreased bone resorption and osteoclast number in the obese state (167). However, the inflammatory properties of immune cells in BM also have not been investigated following these interventions.

The effects of caloric restriction on bone health is still poorly understood. Generally, caloric restriction, accompanied with weight loss, has a positive effect on systemic glucose tolerance and inflammatory status of immune cells and their count (neutrophils) $(169,174)$. A recent study by Collins et al. (160) showed that dietary caloric restriction protects BM and optimizes immunological responses of immune cells by enhanced accumulation of memory $\mathrm{T}$ lymphocytes in BM, erythropoiesis and bone marrow adiposity. However, caloric restriction or starvation in growing mice leads to increased accumulation of bone marrow fat even though peripheral adipose tissue (AT) mass is decreased. Further, it causes decreased bone density and increased bone resorption $(161,198,199)$. Caloric restriction had a similar effect in patients with anorexia nervosa (200). However, in the obese condition, caloric restriction may have a positive effect, as evidenced by reduced bone adiposity and improvement of bone density and chondrogenesis. Although no results on inflammatory components in BM have been measured in this setting $(178,181,182)$.

In the context of inflammatory cytokine production, a recent publication showed that reduced intake of amino acids may inhibit secretion of pro-inflammatory mediator IL- $1 \beta$ mediated by myeloid precursors in BM (See also examples in Table 3) (129). However, for most of the above-mentioned inflammatory proteins (Table 3) (e.g., MCP1, TNF $\alpha$, LIF, CTSK, CXCL16, CTHRC1, Del-1, or TN-C), there is a lack of information in the literature about the modulation of their secretory activity in dietary interventions in $\mathrm{BM}$, which indicates that this area of research needs to be further investigated. Based on the recent publications in relation to life-style interventions and bone health, it suggests that further studies are needed to dissect the role of inflammatory components in BM homeostasis and how these may contribute to local BM and systemic metabolic regulation.

\section{CONCLUSIONS AND PERSPECTIVES}

$\mathrm{BM}$ is an important immune organ, whereby immune and progenitor cells with different functions interact with each other and affect local and systemic immune conditions in response to metabolic and inflammatory stressors, including obesity. Obesity leads to a pro-inflammatory state, which influences metabolic function in insulin-responsive tissues including bone and its immune compartment, BM. Further, the obesogenic condition induces BM hyperplasia defined by increased number of immune cells (monocytes, neutrophils, thrombocytes etc.) migrating into the circulation, which are usually primed in higher inflammatory responses to activate inflammation in peripheral tissues.

How can we define an inflammation in BM? Is it a process of bone resorption defined by activation and expansion of osteoclasts in BM or a process accompanied by increased secretion of inflammatory cytokines, which we know from definition of inflammation in peripheral tissues? And how is it affected in metabolic complications? Most studies have reported changes on the level of osteoclast resorption activity, but not much on secretory properties of immune cells in BM niche. Another aspect of inflammatory status in BM is the immunosuppressive properties of BMSCs, which also contribute to immune regulation in BM microenvironment through cell to cell interactions and secretory bioactive molecules to maintain BM homeostasis.

Undoubtedly, metabolic stressors such as obesity interrupt the existing balance among BMSC and HSC functions, which further affect systemic whole-body immune regulation in relation to metabolic status of organism. Many bone cell-secreted molecules have been found to play an important role in the regulation of AT development (e.g., RANKL, CTSK, and CTHRC1) (201-203) (Figure 2). Therefore, studying their function in relation to bone and fat metabolism is of interest. However, more studies are 


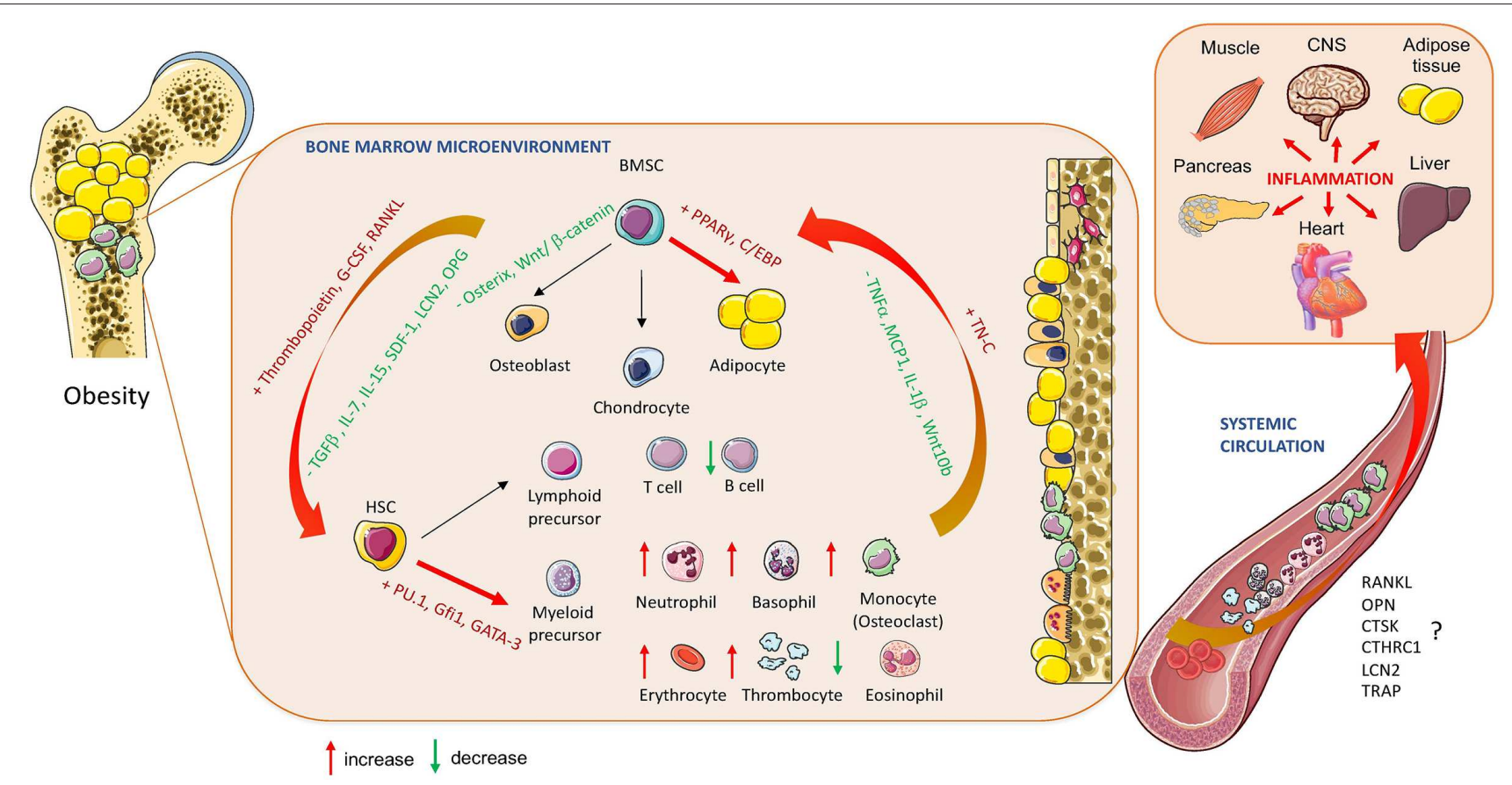

FIGURE 2 | Obesity-induced changes in bone marrow homeostasis. The effect of obesity on BM cellular composition and secretory profile of bioactive molecules produced by hematopoietic stem cells (HSCs) and bone marrow mesenchymal stem cells (BMSCs) in relation to systemic changes affecting whole-body metabolism and inflammation (RANKL, Receptor activator of nuclear factor-к $\beta$ ligand; OPN, Osteopontin; CTSK, Cathepsin K; CTHRC1, Collagen triple helix repeat containing 1; LCN2, lipocalin 2; TRAP, Tartrate-resistant acid phosphatase; OPG, Oteoprotegerin; TGF-B, Transforming growth factor beta; IL-7, Interleukin 7; IL:15, Interleukin 15; IL1-B, Interleukin 1 beta; SDF-1, Stromal cell derived factor; TNF $\alpha$, Tumor necrosis factor alpha; MCP1, Monocyte chemoattractant protein 1; TN-C, Tenascine C; PPAR $\gamma$, peroxisome proliferated-activated receptor gamma; C/EBP, CAAT enhancer binding protein; Gfi1, Zinc finger protein Gfi1; GATA3, GATA binding protein 2). Cell animations were adapted from SERVIER Medical Art; https://smart.servier.com to create the figure.

needed to understand the role of inflammatory changes and crosstalk between immune cells and BMSCs in BM in response to obesity and how these changes can be modulated with targeted therapies focused on treatment for bone and metabolic complications.

\section{AUTHOR CONTRIBUTIONS}

$\mathrm{AB}$ and $\mathrm{MT}$ researched data and wrote the manuscript. MT reviewed and edited the manuscript.

\section{REFERENCES}

1. Hindorf C, Glatting G, Chiesa C, Linden O, Flux G, Committee ED. EANM Dosimetry Committee guidelines for bone marrow and wholebody dosimetry. Eur J Nucl Med Mol Imaging. (2010) 37:1238-50. doi: 10.1007/s00259-010-1422-4

2. Greer JP. Windrobe's Clinical Hematology, 14th ed. Philadelphia: Wolters Kluwer (2019). p. 1-2312.

3. Zhao E, Xu H, Wang L, Kryczek I, Wu K, Hu Y, et al. Bone marrow and the control of immunity. Cell Mol Immunol. (2012) 9:11-9. doi: $10.1038 / \mathrm{cmi} .2011 .47$

4. Tencerova M, Kassem M. The bone marrow-derived stromal cells: commitment and regulation of adipogenesis. Front Endocrinol. (2016) 7:127. doi: $10.3389 /$ fendo.2016.00127

\section{FUNDING}

This work was supported by START UP Research programme by IPHYS and the Czech Science Foundation GACR 20-03586S (PI: MT).

\section{ACKNOWLEDGMENTS}

We thank Dr. Siobhan Craige and Sarah Donelly for the proofreading.

5. Schneider RK, Puellen A, Kramann R, Raupach K, Bornemann J, Knuechel R, et al. The osteogenic differentiation of adult bone marrow and perinatal umbilical mesenchymal stem cells and matrix remodelling in three-dimensional collagen scaffolds. Biomaterials. (2010) 31:467-80. doi: 10.1016/j.biomaterials.2009.09.059

6. Zhang ZY, Teoh SH, Chong MS, Lee ES, Tan LG, Mattar CN, et al. Neo-vascularization and bone formation mediated by fetal mesenchymal stem cell tissue-engineered bone grafts in critical-size femoral defects. Biomaterials. (2010) 31:608-20. doi: 10.1016/j.biomaterials.2009. 09.078

7. Yin T, Li L. The stem cell niches in bone. J Clin Invest. (2006) 116:1195-201. doi: $10.1172 /$ JCI28568

8. Lemoli RM, D'Addio A. Hematopoietic stem cell mobilization. Haematologica. (2008) 93:321-4. doi: 10.3324/haematol.12616 
9. Cottler-Fox MH, Lapidot T, Petit I, Kollet O, DiPersio JF, Link D, et al. Stem cell mobilization. Hematol Am Soc Hematol Educ Prog. (2003) 419-37. doi: 10.1182/asheducation-2003.1.419

10. Sahin AO, Buitenhuis M. Molecular mechanisms underlying adhesion and migration of hematopoietic stem cells. Cell Adh Migr. (2012) 6:39-48. doi: $10.4161 /$ cam. 18975

11. Mazo IB, Massberg S, von Andrian UH. Hematopoietic stem and progenitor cell trafficking. Trends Immunol. (2011) 32:493-503. doi: 10.1016/j.it.2011.06.011

12. Oliveira MC, Vullings J, van de Loo FAJ. Osteoporosis and osteoarthritis are two sides of the same coin paid for obesity. Nutrition. (2019) 70:110486. doi: 10.1016/j.nut.2019.04.001

13. Caplan AI. Mesenchymal stem cells. J Orthop Res. (1991) 9:641-50. doi: 10.1002/jor.1100090504

14. Feuerer M, Beckhove P, Mahnke Y, Hommel M, Kyewski B, Hamann A, et al. Bone marrow microenvironment facilitating dendritic cell: CD4 T cell interactions and maintenance of CD4 memory. Int J Oncol. (2004) 25:86776. doi: 10.3892/ijo.25.4.867

15. Schirrmacher V, Feuerer M, Fournier P, Ahlert T, Umansky V, Beckhove P. T-cell priming in bone marrow: the potential for long-lasting protective anti-tumor immunity. Trends Mol Med. (2003) 9:526-34. doi: 10.1016/j.molmed.2003.10.001

16. Minges Wols HA, Underhill GH, Kansas GS, Witte PL. The role of bone marrow-derived stromal cells in the maintenance of plasma cell longevity. J Immunol. (2002) 169:4213-21. doi: 10.4049/jimmunol.169.8.4213

17. Zeng D, Gazit G, Dejbakhsh-Jones S, Balk SP, Snapper S, Taniguchi M, et al. Heterogeneity of NK1.1+ T cells in the bone marrow: divergence from the thymus. J Immunol. (1999) 163:5338-45.

18. Banchereau J, Briere F, Caux C, Davoust J, Lebecque S, Liu YJ, et al. Immunobiology of dendritic cells. Annu Rev Immunol. (2000) 18:767-811. doi: 10.1146/annurev.immunol.18.1.767

19. Terstappen LW, Levin J. Bone marrow cell differential counts obtained by multidimensional flow cytometry. Blood Cells. (1992) 18:311-30.

20. Cartwright GE, Athens JW, Wintrobe MM. The kinetics of granulopoiesis in normal man. Blood. (1964) 24:780-803. doi: 10.1182/blood.V24.6.780.780

21. Rankin SM. The bone marrow: a site of neutrophil clearance. J Leukoc Biol. (2010) 88:241-51. doi: 10.1189/jlb.0210112

22. Shadduck RK, Waheed A, Wing EJ. Demonstration of a blood-bone marrow barrier to macrophage colony-stimulating factor. Blood. (1989) 73:68-73. doi: 10.1182/blood.V73.1.68.68

23. Itkin T, Gur-Cohen S, Spencer JA, Schajnovitz A, Ramasamy SK, Kusumbe AP, et al. Distinct bone marrow blood vessels differentially regulate haematopoiesis. Nature. (2016) 532:323-8. doi: 10.1038/nature17624

24. Kopp HG, Avecilla ST, Hooper AT, Rafii S. The bone marrow vascular niche: home of HSC differentiation and mobilization. Physiology. (2005) 20:349-56. doi: 10.1152/physiol.00025.2005

25. Adler BJ, Kaushansky K, Rubin CT. Obesity-driven disruption of haematopoiesis and the bone marrow niche. Nat Rev Endocrinol. (2014) 10:737-48. doi: 10.1038/nrendo.2014.169

26. Birbrair, Frenette PS. Niche heterogeneity in the bone marrow. Ann N Y Acad Sci. (2016) 1370:82-96. doi: 10.1111/nyas.13016

27. Rharass T, Lucas S. Mechanisms in endocrinology: bone marrow adiposity and bone, a bad romance? Eur J Endocrinol. (2018) 179:R165-82. doi: 10.1530/EJE-18-0182

28. Mendelson, Frenette PS. Hematopoietic stem cell niche maintenance during homeostasis and regeneration. Nat Med. (2014) 20:833-46. doi: $10.1038 / \mathrm{nm} .3647$

29. Wilson NK, Calero-Nieto FJ, Ferreira R, Gottgens B. Transcriptional regulation of haematopoietic transcription factors. Stem Cell Res Ther. (2011) 2:6. doi: 10.1186/scrt47

30. Wilson, Murphy MJ, Oskarsson T, Kaloulis K, Bettess MD, Oser GM, et al. cMyc controls the balance between hematopoietic stem cell self-renewal and differentiation. Genes Dev. (2004) 18:2747-63. doi: 10.1101/gad.313104

31. Smith LT, Hohaus S, Gonzalez DA, Dziennis SE, Tenen DG. PU.1 (Spi-1) and C/EBP alpha regulate the granulocyte colony-stimulating factor receptor promoter in myeloid cells. Blood. (1996) 88:1234-47. doi: 10.1182/blood.V88.4.1234.bloodjournal8841234
32. Hohaus S, Petrovick MS, Voso MT, Sun Z, Zhang DE, Tenen DG. PU.1 (Spi-1) and C/EBP alpha regulate expression of the granulocyte-macrophage colony-stimulating factor receptor alpha gene. Mol Cell Biol. (1995) 15:583045. doi: 10.1128/MCB.15.10.5830

33. Zhang DE, Hetherington CJ, Chen HM, Tenen DG. The macrophage transcription factor PU.1 directs tissue-specific expression of the macrophage colony-stimulating factor receptor. Mol Cell Biol. (1994) 14:373-81. doi: 10.1128/MCB.14.1.373

34. Rothenberg EV, Hosokawa H, Ungerback J. Mechanisms of action of hematopoietic transcription factor PU.1 in initiation of T-cell development. Front Immunol. (2019) 10:228. doi: 10.3389/fimmu.2019.00228

35. Georgopoulos K, Bigby M, Wang JH, Molnar A, Wu P, Winandy S, et al. The Ikaros gene is required for the development of all lymphoid lineages. Cell. (1994) 79:143-56. doi: 10.1016/0092-8674(94)90407-3

36. Wang J, Sun Q, Morita Y, Jiang H, Gross A, Lechel A, et al. A differentiation checkpoint limits hematopoietic stem cell self-renewal in response to DNA damage. Cell. (2012) 148:1001-14. doi: 10.1016/j.cell.2012.01.040

37. Wang X, Dong F, Zhang S, Yang W, Yu W, Wang Z, et al. TGF-betal negatively regulates the number and function of hematopoietic stem cells. Stem Cell Rep. (2018) 11:274-87. doi: 10.1016/j.stemcr.2018.05.017

38. Bresnick EH, Katsumura KR, Lee HY, Johnson KD, Perkins AS. Master regulatory GATA transcription factors: mechanistic principles and emerging links to hematologic malignancies. Nucleic Acids Res. (2012) 40:5819-31. doi: 10.1093/nar/gks281

39. Rizo, Dontje B, Vellenga E, de Haan G, Schuringa JJ. Long-term maintenance of human hematopoietic stem/progenitor cells by expression of BMI1. Blood. (2008) 111:2621-30. doi: 10.1182/blood-2007-08-106666

40. Rizo, Olthof S, Han L, Vellenga E, de Haan G, Schuringa JJ. Repression of BMI1 in normal and leukemic human CD34(+) cells impairs self-renewal and induces apoptosis. Blood. (2009) 114:1498-505. doi: 10.1182/blood-2009-03-209734

41. Lee JM, Govindarajah V, Goddard B, Hinge A, Muench DE, Filippi MD, et al. Obesity alters the long-term fitness of the hematopoietic stem cell compartment through modulation of Gfil expression. J Exp Med. (2018) 215:627-44. doi: 10.1084/jem.20170690

42. Buisman SC, de Haan G. Epigenetic changes as a target in aging haematopoietic stem cells and age-related malignancies. Cells. (2019) 8:868. doi: 10.3390/cells 8080868

43. Florian MC, Dorr K, Niebel A, Daria D, Schrezenmeier H, Rojewski M, et al. Cdc42 activity regulates hematopoietic stem cell aging and rejuvenation. Cell Stem Cell. (2012) 10:520-30. doi: 10.1016/j.stem.2012.04.007

44. Chen X, Skutt-Kakaria K, Davison J, Ou YL, Choi E, Malik P, et al. G9a/GLP-dependent histone H3K9me2 patterning during human hematopoietic stem cell lineage commitment. Genes Dev. (2012) 26:2499511. doi: 10.1101/gad.200329.112

45. Trowbridge JJ, Snow JW, Kim J, Orkin SH. DNA methyltransferase 1 is essential for and uniquely regulates hematopoietic stem and progenitor cells. Cell Stem Cell. (2009) 5:442-9. doi: 10.1016/j.stem.2009.08.016

46. Komori T, Yagi H, Nomura S, Yamaguchi A, Sasaki K, Deguchi K, et al. Targeted disruption of Cbfal results in a complete lack of bone formation owing to maturational arrest of osteoblasts. Cell. (1997) 89:75564. doi: 10.1016/S0092-8674(00)80258-5

47. Nakashima K, Zhou X, Kunkel G, Zhang Z, Deng JM, Behringer RR, et al. The novel zinc finger-containing transcription factor osterix is required for osteoblast differentiation and bone formation. Cell. (2002) 108:17-29. doi: 10.1016/S0092-8674(01)00622-5

48. Kamata M, Okitsu Y, Fujiwara T, Kanehira M, Nakajima S, Takahashi T, et al. GATA2 regulates differentiation of bone marrow-derived mesenchymal stem cells. Haematologica. (2014) 99:1686-96. doi: 10.3324/haematol.2014.105692

49. Tolkachov, Fischer C, Ambrosi TH, Bothe M, Han CT, Muenzner M, et al. Loss of the hematopoietic stem cell factor GATA2 in the osteogenic lineage impairs trabecularization and mechanical strength of bone. Mol Cell Biol. (2018) 38:e00599-17. doi: 10.1128/MCB.00599-17

50. Muruganandan S, Roman AA, Sinal CJ. Adipocyte differentiation of bone marrow-derived mesenchymal stem cells: cross talk with the osteoblastogenic program. Cell Mol Life Sci. (2009) 66:236-53. doi: $10.1007 /$ s00018-008-8429-z 
51. Cho HH, Park HT, Kim YJ, Bae YC, Suh KT, Jung JS. Induction of osteogenic differentiation of human mesenchymal stem cells by histone deacetylase inhibitors. J Cell Biochem. (2005) 96:533-42. doi: 10.1002/jcb.20544

52. Schroeder TM, Westendorf JJ. Histone deacetylase inhibitors promote osteoblast maturation. J Bone Miner Res. (2005) 20:2254-63. doi: 10.1359/JBMR.050813

53. Addison WN, Fu MM, Yang HX, Lin Z, Nagano K, Gori F, et al. Direct transcriptional repression of Zfp423 by Zfp521 mediates a bone morphogenic protein-dependent osteoblast versus adipocyte lineage commitment switch. Mol Cell Biol. (2014) 34:3076-85. doi: 10.1128/MCB.00185-14

54. Liu A, Chen M, Kumar R, Stefanovic-Racic M, O'Doherty RM, Ding Y, et al. Bone marrow lympho-myeloid malfunction in obesity requires precursor cell-autonomous TLR4. Nat Commun. (2018) 9:708. doi: 10.1038/s41467-018-03145-8

55. Lackey DE, Reis FCG, Isaac R, Zapata RC, El Ouarrat D, Lee YS, et al. Adipocyte PU.1 knockout promotes insulin sensitivity in HFD-fed obese mice. Sci Rep. (2019) 9:14779. doi: 10.1038/s41598-019-51196-8

56. Lampreia FP, Carmelo JG, Anjos-Afonso F. Notch signaling in the regulation of hematopoietic stem cell. Curr Stem Cell Rep. (2017) 3:202-9. doi: 10.1007/s40778-017-0090-8

57. Sasaki T, Moro K, Kubota T, Kubota N, Kato T, Ohno H, et al. Innate lymphoid cells in the induction of obesity. Cell Rep. (2019) 28:202-17 e7. doi: 10.1016/j.celrep.2019.06.016

58. Zeng H, Yucel R, Kosan C, Klein-Hitpass L, Moroy T. Transcription factor Gfil regulates self-renewal and engraftment of hematopoietic stem cells. EMBO J. (2004) 23:4116-25. doi: 10.1038/sj.emboj.7600419

59. Tang EH, Shimizu K, Christen T, Rocha VZ, Shvartz E, Tesmenitsky Y, et al. Lack of EP4 receptors on bone marrow-derived cells enhances inflammation in atherosclerotic lesions. Cardiovasc Res. (2011) 89:234-43. doi: $10.1093 / \mathrm{cvr} / \mathrm{cvq} 262$

60. Tencerova M, Figeac F, Ditzel N, Taipaleenmaki H, Nielsen TK, Kassem M. High-fat diet-induced obesity promotes expansion of bone marrow adipose tissue and impairs skeletal stem cell functions in mice. J Bone Miner Res. (2018) 33:1154-65. doi: 10.1002/jbmr.3408

61. Zhou Y, Guan X, Zhu Z, Gao S, Zhang C, Li C, et al. Osteogenic differentiation of bone marrow-derived mesenchymal stromal cells on bonederived scaffolds: effect of microvibration and role of ERK1/2 activation. Eur Cell Mater. (2011) 22:12-25. doi: 10.22203/eCM.v022a02

62. Emmons R, Niemiro GM, De Lisio M. Hematopoiesis with obesity and exercise: role of the bone marrow niche. Exerc Immunol Rev. (2017) 23:8295. doi: 10.1155/2016/7131359

63. Lau E, Lee WD, Li J, Xiao A, Davies JE, Wu Q, et al. Effect of low-magnitude, high-frequency vibration on osteogenic differentiation of rat mesenchymal stromal cells. J Orthop Res. (2011) 29:1075-80. doi: 10.1002/jor.21334

64. Zhao Q, Lu Y, Gan X, Yu H. Low magnitude high frequency vibration promotes adipogenic differentiation of bone marrow stem cells via P38 MAPK signal. PLoS ONE. (2017) 12:e0172954. doi: 10.1371/journal.pone.0172954

65. Tontonoz P, Spiegelman BM. Fat and beyond: the diverse biology of PPARgamma. Annu Rev Biochem. (2008) 77:289-312. doi: 10.1146/annurev.biochem.77.061307.091829

66. Hermetet F, Buffiere A, Aznague A, Pais de Barros JP, Bastie JN, Delva L, et al. High-fat diet disturbs lipid raft/TGF-beta signaling-mediated maintenance of hematopoietic stem cells in mouse bone marrow. Nat Commun. (2019) 10:523. doi: 10.1038/s41467-018-08228-0

67. Roy B, Curtis ME, Fears LS, Nahashon SN, Fentress HM. Molecular mechanisms of obesity-induced osteoporosis and muscle atrophy. Front Physiol. (2016) 7:439. doi: 10.3389/fphys.2016.00439

68. Periyasamy-Thandavan S, Herberg S, Arounleut P, Upadhyay S, Dukes A, Davis C, et al. Caloric restriction and the adipokine leptin alter the SDF-1 signaling axis in bone marrow and in bone marrow derived mesenchymal stem cells. Mol Cell Endocrinol. (2015) 410:64-72. doi: 10.1016/j.mce.2015.03.001

69. Klyushnenkova E, Mosca JD, Zernetkina V, Majumdar MK, Beggs KJ, Simonetti DW, et al. T cell responses to allogeneic human mesenchymal stem cells: immunogenicity, tolerance, and suppression. J Biomed Sci. (2005) 12:47-57. doi: 10.1007/s11373-004-8183-7
70. Di Nicola M, Carlo-Stella C, Magni M, Milanesi M, Longoni PD, Matteucci P, et al. Human bone marrow stromal cells suppress T-lymphocyte proliferation induced by cellular or nonspecific mitogenic stimuli. Blood. (2002) 99:383843. doi: 10.1182/blood.V99.10.3838

71. Krampera M, Glennie S, Dyson J, Scott D, Laylor R, Simpson E, et al. Bone marrow mesenchymal stem cells inhibit the response of naive and memory antigen-specific T cells to their cognate peptide. Blood. (2003) 101:3722-9. doi: 10.1182/blood-2002-07-2104

72. Liang, Jiang E, Yao J, Wang $M$, Chen $S$, Zhou Z, et al. Interferongamma mediates the immunosuppression of bone marrow mesenchymal stem cells on T-lymphocytes in vitro. Hematology. (2018) 23:44-9. doi: 10.1080/10245332.2017.1333245

73. Corcione A, Benvenuto F, Ferretti E, Giunti D, Cappiello V, Cazzanti F, et al. Human mesenchymal stem cells modulate B-cell functions. Blood. (2006) 107:367-72. doi: 10.1182/blood-2005-07-2657

74. Jiang XX, Zhang Y, Liu B, Zhang SX, Wu Y, Yu XD, et al. Human mesenchymal stem cells inhibit differentiation and function of monocyte-derived dendritic cells. Blood. (2005) 105:4120-6. doi: 10.1182/blood-2004-02-0586

75. Nauta AJ, Kruisselbrink AB, Lurvink E, Willemze R, Fibbe WE. Mesenchymal stem cells inhibit generation and function of both CD34+derived and monocyte-derived dendritic cells. J Immunol. (2006) 177:20807. doi: 10.4049/jimmunol.177.4.2080

76. Sotiropoulou PA, Perez SA, Gritzapis AD, Baxevanis CN, Papamichail M. Interactions between human mesenchymal stem cells and natural killer cells. Stem Cells. (2006) 24:74-85. doi: 10.1634/stemcells.2004-0359

77. Spaggiari GM, Capobianco A, Abdelrazik H, Becchetti F, Mingari MC, Moretta L. Mesenchymal stem cells inhibit natural killer-cell proliferation, cytotoxicity, and cytokine production: role of indoleamine 2,3-dioxygenase and prostaglandin E2. Blood. (2008) 111:1327-33. doi: 10.1182/blood-2007-02-074997

78. Horwitz EM, Prockop DJ, Fitzpatrick LA, Koo WW, Gordon PL, Neel $\mathrm{M}$, et al. Transplantability and therapeutic effects of bone marrow-derived mesenchymal cells in children with osteogenesis imperfecta. Nat Med. (1999) 5:309-13. doi: 10.1038/6529

79. Bang OY, Lee JS, Lee PH, Lee G. Autologous mesenchymal stem cell transplantation in stroke patients. Ann Neurol. (2005) 57:874-82. doi: 10.1002/ana.20501

80. Carvello M, Lightner A, Yamamoto T, Kotze PG, Spinelli A. Mesenchymal stem cells for perianal Crohn's disease. Cells. (2019) 8:764. doi: $10.3390 /$ cells 8070764

81. Dige A, Hougaard HT, Agnholt J, Pedersen BG, Tencerova M, Kassem M, et al. Efficacy of injection of freshly collected autologous adipose tissue into perianal fistulas in patients with Crohn's disease. Gastroenterology. (2019) 156:2208-16 e1. doi: 10.1053/j.gastro.2019.02.005

82. Mollard RC, Gillam ME, Wood TM, Taylor CG, Weiler HA. (n-3) fatty acids reduce the release of prostaglandin E2 from bone but do not affect bone mass in obese (fa/fa) and lean Zucker rats. J Nutr. (2005) 135:499-504. doi: 10.1093/jn/135.3.499

83. Miller JP, Izon D, DeMuth W, Gerstein R, Bhandoola A, Allman D. The earliest step in B lineage differentiation from common lymphoid progenitors is critically dependent upon interleukin 7. J Exp Med. (2002) 196:705-11. doi: $10.1084 /$ jem.20020784

84. Adler BJ, Green DE, Pagnotti GM, Chan ME, Rubin CT. High fat diet rapidly suppresses B lymphopoiesis by disrupting the supportive capacity of the bone marrow niche. PLoS ONE. (2014) 9:e90639. doi: 10.1371/journal.pone.0090639

85. Becker TC, Wherry EJ, Boone D, Murali-Krishna K, Antia R, Ma A, et al. Interleukin 15 is required for proliferative renewal of virus-specific memory CD8 T cells. J Exp Med. (2002) 195:1541-8. doi: 10.1084/jem.20020369

86. Nielsen AR, Hojman P, Erikstrup C, Fischer CP, Plomgaard P, Mounier R, et al. Association between interleukin-15 and obesity: interleukin-15 as a potential regulator of fat mass. J Clin Endocrinol Metab. (2008) 93:4486-93. doi: $10.1210 /$ jc.2007-2561

87. Parrish-Novak J, Dillon SR, Nelson A, Hammond A, Sprecher C, Gross $\mathrm{JA}$, et al. Interleukin 21 and its receptor are involved in NK cell expansion and regulation of lymphocyte function. Nature. (2000) 408:57-63. doi: $10.1038 / 35040504$ 
88. Pronk CJ, Veiby OP, Bryder D, Jacobsen SE. Tumor necrosis factor restricts hematopoietic stem cell activity in mice: involvement of two distinct receptors. J Exp Med. (2011) 208:1563-70. doi: 10.1084/jem.20110752

89. van den Berg SM, Seijkens TT, Kusters PJ, Beckers L, den Toom M, Smeets E, et al. Diet-induced obesity in mice diminishes hematopoietic stem and progenitor cells in the bone marrow. FASEB J. (2016) 30:1779-88. doi: 10.1096/fj.201500175

90. Avecilla ST, Hattori K, Heissig B, Tejada R, Liao F, Shido K, et al. Chemokinemediated interaction of hematopoietic progenitors with the bone marrow vascular niche is required for thrombopoiesis. Nat Med. (2004) 10:64-71. doi: $10.1038 / \mathrm{nm} 973$

91. Peled A, Kollet O, Ponomaryov T, Petit I, Franitza S, Grabovsky V, et al. The chemokine SDF-1 activates the integrins LFA-1, VLA-4, and VLA5 on immature human $\mathrm{CD} 34(+)$ cells: role in transendothelial/stromal migration and engraftment of NOD/SCID mice. Blood. (2000) 95:3289-96. doi: 10.1182/blood.V95.11.3289.011k33_3289_3296

92. Ferraro F, Lymperi S, Mendez-Ferrer S, Saez B, Spencer JA, Yeap BY, et al. Diabetes impairs hematopoietic stem cell mobilization by altering niche function. Sci Transl Med. (2011) 3:104ra101. doi: 10.1126/scitranslmed.3002191

93. Chang E, Paterno J, Duscher D, Maan ZN, Chen JS, Januszyk M, et al. Exercise induces stromal cell-derived factor-1alpha-mediated release of endothelial progenitor cells with increased vasculogenic function. Plast Reconstr Surg. (2015) 135:340-50e. doi: 10.1097/PRS.00000000000 00917

94. Yoshihara H, Arai F, Hosokawa K, Hagiwara T, Takubo K, Nakamura Y, et al. Thrombopoietin/MPL signaling regulates hematopoietic stem cell quiescence and interaction with the osteoblastic niche. Cell Stem Cell. (2007) 1:685-97. doi: 10.1016/j.stem.2007.10.020

95. Nagahisa H, Nagata Y, Ohnuki T, Osada M, Nagasawa T, Abe T, et al. Bone marrow stromal cells produce thrombopoietin and stimulate megakaryocyte growth and maturation but suppress proplatelet formation. Blood. (1996) 87:1309-16. doi: 10.1182/blood.V87.4.1309.bloodjournal8741309

96. Kraakman MJ, Lee MK, Al-Sharea A, Dragoljevic D, Barrett TJ, Montenont E, et al. Neutrophil-derived S100 calcium-binding proteins A8/A9 promote reticulated thrombocytosis and atherogenesis in diabetes. J Clin Invest. (2017) 127:2133-47. doi: 10.1172/JCI92450

97. Coban E, Yilmaz A, Sari R. The effect of weight loss on the mean platelet volume in obese patients. Platelets. (2007) 18:212-6. doi: 10.1080/09537100600975362

98. Arai F, Hirao A, Ohmura M, Sato H, Matsuoka S, Takubo K, et al. Tie2/angiopoietin-1 signaling regulates hematopoietic stem cell quiescence in the bone marrow niche. Cell. (2004) 118:149-61. doi: 10.1016/j.cell.2004.07.004

99. Keats EC, Dominguez JM II, Grant MB, Khan ZA. Switch from canonical to noncanonical Wnt signaling mediates high glucose-induced adipogenesis. Stem Cells. (2014) 32:1649-60. doi: 10.1002/stem.1659

100. Li Z, Hardij J, Evers SS, Hutch CR, Choi SM, Shao Y, et al. G-CSF partially mediates effects of sleeve gastrectomy on the bone marrow niche. J Clin Invest. (2019) 129:2404-16. doi: 10.1172/JCI126173

101. Trottier MD, Naaz A, Li Y, Fraker PJ. Enhancement of hematopoiesis and lymphopoiesis in diet-induced obese mice. Proc Natl Acad Sci USA. (2012) 109:7622-9. doi: 10.1073/pnas.1205129109

102. do Carmo LS, Rogero MM, Paredes-Gamero EJ, Nogueira-Pedro A, Xavier JG, Cortez M, et al. A high-fat diet increases interleukin-3 and granulocyte colony-stimulating factor production by bone marrow cells and triggers bone marrow hyperplasia and neutrophilia in Wistar rats. Exp Biol Med. (2013) 238:375-84. doi: 10.1177/1535370213477976

103. Boyle WJ, Simonet WS, Lacey DL. Osteoclast differentiation and activation. Nature. (2003) 423:337-42. doi: 10.1038/nature01658

104. Halade GV, El Jamali A, Williams PJ, Fajardo RJ, Fernandes G. Obesity-mediated inflammatory microenvironment stimulates osteoclastogenesis and bone loss in mice. Exp Gerontol. (2011) 46:43-52. doi: 10.1016/j.exger.2010.09.014

105. Kim JY, Kim HJ, Kim CS. Effects of 12-week combined exercise on RANKL/RANK/OPG signaling and bone-resorption cytokines in healthy college females. J Exerc Nutr Biochem. (2019) 23:13-20. doi: $10.20463 /$ jenb.2019.0003
106. Costa A, Principi E, Lazzarini E, Descalzi F, Cancedda R, Castagnola P, et al. LCN2 overexpression in bone enhances the hematopoietic compartment via modulation of the bone marrow microenvironment. J Cell Physiol. (2017) 232:3077-87. doi: 10.1002/jcp.25755

107. Carrancio S, Blanco B, Romo C, Muntion S, Lopez-Holgado N, Blanco JF, et al. Bone marrow mesenchymal stem cells for improving hematopoietic function: an in vitro and in vivo model. Part 2: effect on bone marrow microenvironment. PLoS ONE. (2011) 6:e26241. doi: 10.1371/journal.pone.0026241

108. Majumdar MK, Thiede MA, Haynesworth SE, Bruder SP, Gerson SL. Human marrow-derived mesenchymal stem cells (MSCs) express hematopoietic cytokines and support long-term hematopoiesis when differentiated toward stromal and osteogenic lineages. J Hematother Stem Cell Res. (2000) 9:841-8. doi: 10.1089/152581600750062264

109. Qian H, Buza-Vidas N, Hyland CD, Jensen CT, Antonchuk J, Mansson R, et al. Critical role of thrombopoietin in maintaining adult quiescent hematopoietic stem cells. Cell Stem Cell. (2007) 1:671-84. doi: 10.1016/j.stem.2007.10.008

110. Petit A, Szyper-Kravitz M, Nagler A, Lahav M, Peled A, Habler L, et al. GCSF induces stem cell mobilization by decreasing bone marrow SDF-1 and up-regulating CXCR4. Nat Immunol. (2002) 3:687-94. doi: 10.1038/ni813

111. Peled A, Petit I, Kollet O, Magid M, Ponomaryov T, Byk T, et al. Dependence of human stem cell engraftment and repopulation of NOD/SCID mice on CXCR4. Science. (1999) 283:845-8. doi: 10.1126/science.283.5403.845

112. Taichman RS, Emerson SG. The role of osteoblasts in the hematopoietic microenvironment. Stem Cells. (1998) 16:7-15. doi: 10.1002/stem.160007

113. Fulzele K, Krause DS, Panaroni C, Saini V, Barry KJ, Liu X, et al. Myelopoiesis is regulated by osteocytes through Gsalpha-dependent signaling. Blood. (2013) 121:930-9. doi: 10.1182/blood-2012-06-437160

114. Weissman IL. Stem cells: units of development, units of regeneration, and units in evolution. Cell. (2000) 100:157-68. doi: 10.1016/S0092-8674(00)81692-X

115. Kondo M, Wagers AJ, Manz MG, Prohaska SS, Scherer DC, Beilhack GF, et al. Biology of hematopoietic stem cells and progenitors: implications for clinical application. Annu Rev Immunol. (2003) 21:759-806. doi: 10.1146/annurev.immunol.21.120601.141007

116. Bryder, Rossi DJ, Weissman IL. Hematopoietic stem cells: the paradigmatic tissue-specific stem cell. Am J Pathol. (2006) 169:338-46. doi: 10.2353/ajpath.2006.060312

117. Kawamoto H, Katsura Y. A new paradigm for hematopoietic cell lineages: revision of the classical concept of the myeloid-lymphoid dichotomy. Trends Immunol. (2009) 30:193-200. doi: 10.1016/j.it.2009.03.001

118. Ema H, Morita Y, Suda T. Heterogeneity and hierarchy of hematopoietic stem cells. Exp Hematol. (2014) 42:74-82 e2. doi: 10.1016/j.exphem.2013.11.004

119. Ramalingam P, Poulos MG, Butler JM. Regulation of the hematopoietic stem cell lifecycle by the endothelial niche. Curr Opin Hematol. (2017) 24:289-99. doi: 10.1097/MOH.0000000000000350

120. Asada N, Kunisaki Y, Pierce H, Wang Z, Fernandez NF, Birbrair A, et al. Differential cytokine contributions of perivascular haematopoietic stem cell niches. Nat Cell Biol. (2017) 19:214-23. doi: 10.1038/ncb3475

121. Zhao M, Perry JM, Marshall H, Venkatraman A, Qian P, He XC, et al. Megakaryocytes maintain homeostatic quiescence and promote post-injury regeneration of hematopoietic stem cells. Nat Med. (2014) 20:1321-6. doi: $10.1038 / \mathrm{nm} .3706$

122. Winkler IG, Sims NA, Pettit AR, Barbier V, Nowlan B, Helwani F, et al. Bone marrow macrophages maintain hematopoietic stem cell (HSC) niches and their depletion mobilizes HSCs. Blood. (2010) 116:4815-28. doi: 10.1182/blood-2009-11-253534

123. Schofield R. The relationship between the spleen colony-forming cell and the haemopoietic stem cell. Blood Cells. (1978) 4:7-25.

124. Whitlock CA, Witte ON. Long-term culture of B lymphocytes and their precursors from murine bone marrow. Proc Natl Acad Sci USA. (1982) 79:3608-12. doi: 10.1073/pnas.79.11.3608

125. Whitlock CA, Tidmarsh GF, Muller-Sieburg C, Weissman IL. Bone marrow stromal cell lines with lymphopoietic activity express high levels of a pre-B neoplasia-associated molecule. Cell. (1987) 48:1009-21. doi: 10.1016/0092-8674(87)90709-4 
126. Nakano T, Kodama H, Honjo T. Generation of lymphohematopoietic cells from embryonic stem cells in culture. Science. (1994) 265:1098-101. doi: $10.1126 /$ science. 8066449

127. Tikhonova AN, Dolgalev I, Hu H, Sivaraj KK, Hoxha E, Cuesta-Dominguez $\mathrm{A}$, et al. The bone marrow microenvironment at single-cell resolution. Nature. (2019) 569:222-8. doi: 10.1038/s41586-019-1104-8

128. Mirantes C, Passegue E, Pietras EM. Pro-inflammatory cytokines: emerging players regulating HSC function in normal and diseased hematopoiesis. Exp Cell Res. (2014) 329:248-54. doi: 10.1016/j.yexcr.2014.08.017

129. Battu S, Afroz S, Giddaluru J, Naz S, Huang W, Khumukcham SS, et al. Amino acid starvation sensing dampens IL-1beta production by activating riboclustering and autophagy. PLoS Biol. (2018) 16:e2005317. doi: 10.1371/journal.pbio.2005317

130. Yamashita M, Passegue E. TNF-alpha coordinates hematopoietic stem cell survival and myeloid regeneration. Cell Stem Cell. (2019) 25:357-72 e7. doi: 10.1016/j.stem.2019.05.019

131. Ota K, Quint P, Ruan M, Pederson L, Westendorf JJ, Khosla S, et al. TGFbeta induces Wnt10b in osteoclasts from female mice to enhance coupling to osteoblasts. Endocrinology. (2013) 154:3745-52. doi: 10.1210/en.2013-1272

132. Bennett CN, Longo KA, Wright WS, Suva LJ, Lane TF, Hankenson KD, et al. Regulation of osteoblastogenesis and bone mass by Wnt10b. Proc Natl Acad Sci USA. (2005) 102:3324-9. doi: 10.1073/pnas.0408742102

133. Ota K, Quint P, Weivoda MM, Ruan M, Pederson L, Westendorf JJ, et al. Transforming growth factor beta 1 induces CXCL16 and leukemia inhibitory factor expression in osteoclasts to modulate migration of osteoblast progenitors. Bone. (2013) 57:68-75. doi: 10.1016/j.bone.2013.07.023

134. Hayman AR. Tartrate-resistant acid phosphatase (TRAP) and the osteoclast/immune cell dichotomy. Autoimmunity. (2008) 41:218-23. doi: 10.1080/08916930701694667

135. Lecka-Czernik B, Stechschulte LA, Czernik PJ, Dowling AR. High bone mass in adult mice with diet-induced obesity results from a combination of initial increase in bone mass followed by attenuation in bone formation; implications for high bone mass and decreased bone quality in obesity. Mol Cell Endocrinol. (2015) 410:35-41. doi: 10.1016/j.mce.2015.01.001

136. McGrath C, Sankaran JS, Misaghian-Xanthos N, Sen B, Xie Z, Styner MA, et al. Exercise degrades bone in caloric restriction, despite suppression of Marrow Adipose Tissue (MAT). J Bone Miner Res. (2019) 35:106-15. doi: $10.1002 /$ jbmr.3872

137. Lotinun S, Kiviranta R, Matsubara T, Alzate JA, Neff L, Luth A, et al. Osteoclast-specific cathepsin $\mathrm{K}$ deletion stimulates S1P-dependent bone formation. J Clin Invest. (2013) 123:666-81. doi: 10.1172/JCI64840

138. Kimura H, Kwan KM, Zhang Z, Deng JM, Darnay BG, Behringer RR, et al. Cthrcl is a positive regulator of osteoblastic bone formation. PLoS ONE. (2008) 3:e3174. doi: 10.1371/journal.pone.0003174

139. Mitroulis, Chen LS, Singh RP, Kourtzelis I, Economopoulou M, Kajikawa T, et al. Secreted protein Del-1 regulates myelopoiesis in the hematopoietic stem cell niche. J Clin Invest. (2017) 127:3624-39. doi: 10.1172/JCI92571

140. Nakamura-Ishizu, Okuno Y, Omatsu Y, Okabe K, Morimoto J, Uede T, et al. Extracellular matrix protein tenascin- $\mathrm{C}$ is required in the bone marrow microenvironment primed for hematopoietic regeneration. Blood. (2012) 119:5429-37. doi: 10.1182/blood-2011-11-393645

141. da Silva SV, Renovato-Martins M, Ribeiro-Pereira C, Citelli M, Barja-Fidalgo C. Obesity modifies bone marrow microenvironment and directs bone marrow mesenchymal cells to adipogenesis. Obesity. (2016) 24:2522-32. doi: 10.1002/oby.21660

142. Singh P, Yao Y, Weliver A, Broxmeyer HE, Hong SC, Chang CH. Vaccinia virus infection modulates the hematopoietic cell compartments in the bone marrow. Stem Cells. (2008) 26:1009-16. doi: 10.1634/stemcells.2007-0461

143. Cheshier SH, Prohaska SS, Weissman IL. The effect of bleeding on hematopoietic stem cell cycling and self-renewal. Stem Cells Dev. (2007) 16:707-17. doi: 10.1089/scd.2007.0017

144. Gueders MM, Hirst SJ, Quesada-Calvo F, Paulissen G, Hacha J, Gilles C, et al. Matrix metalloproteinase-19 deficiency promotes tenascin-C accumulation and allergen-induced airway inflammation. Am J Respir Cell Mol Biol. (2010) 43:286-95. doi: 10.1165/rcmb.2008-0426OC

145. Klein G, Beck S, Muller CA. Tenascin is a cytoadhesive extracellular matrix component of the human hematopoietic microenvironment. J Cell Biol. (1993) 123:1027-35. doi: 10.1083/jcb.123.4.1027
146. Nagai Y, Garrett KP, Ohta S, Bahrun U, Kouro T, Akira S, et al. Toll-like receptors on hematopoietic progenitor cells stimulate innate immune system replenishment. Immunity. (2006) 24:801-12. doi: 10.1016/j.immuni.2006.04.008

147. Baldridge MT, King KY, Goodell MA. Inflammatory signals regulate hematopoietic stem cells. Trends Immunol. (2011) 32:57-65. doi: 10.1016/j.it.2010.12.003

148. Baldridge MT, King KY, Boles NC, Weksberg DC, Goodell MA. Quiescent haematopoietic stem cells are activated by IFN-gamma in response to chronic infection. Nature. (2010) 465:793-7. doi: 10.1038/nature09135

149. King KY, Goodell MA. Inflammatory modulation of HSCs: viewing the HSC as a foundation for the immune response. Nat Rev Immunol. (2011) 11:685-92. doi: 10.1038/nri3062

150. Nicholson GC, Malakellis M, Collier FM, Cameron PU, Holloway WR, Gough TJ, et al. Induction of osteoclasts from CD14-positive human peripheral blood mononuclear cells by receptor activator of nuclear factor kappaB ligand (RANKL). Clin Sci. (2000) 99:133-40. doi: 10.1042/cs0990133

151. Suda T, Takahashi N, Udagawa N, Jimi E, Gillespie MT, Martin TJ. Modulation of osteoclast differentiation and function by the new members of the tumor necrosis factor receptor and ligand families. Endocr Rev. (1999) 20:345-57. doi: 10.1210/edrv.20.3.0367

152. Raisz LG. Physiology and pathophysiology of bone remodeling. Clin Chem. (1999) 45:1353-8.

153. Tang Y, Wu X, Lei W, Pang L, Wan C, Shi Z, et al. TGF-betal-induced migration of bone mesenchymal stem cells couples bone resorption with formation. Nat Med. (2009) 15:757-65. doi: 10.1038/nm.1979

154. Xian L, Wu X, Pang L, Lou M, Rosen CJ, Qiu T, et al. Matrix IGF-1 maintains bone mass by activation of mTOR in mesenchymal stem cells. Nat Med. (2012) 18:1095-101. doi: 10.1038/nm.2793

155. Zenger S, Hollberg K, Ljusberg J, Norgard M, Ek-Rylander B, Kiviranta $\mathrm{R}$, et al. Proteolytic processing and polarized secretion of tartrateresistant acid phosphatase is altered in a subpopulation of metaphyseal osteoclasts in cathepsin K-deficient mice. Bone. (2007) 41:820-32. doi: 10.1016/j.bone.2007.07.010

156. Fuller K, Lawrence KM, Ross JL, Grabowska UB, Shiroo M, Samuelsson $\mathrm{B}$, et al. Cathepsin $\mathrm{K}$ inhibitors prevent matrix-derived growth factor degradation by human osteoclasts. Bone. (2008) 42:200-11. doi: 10.1016/j.bone.2007.09.044

157. Takeshita S, Fumoto T, Matsuoka K, Park KA, Aburatani H, Kato S, et al. Osteoclast-secreted CTHRC1 in the coupling of bone resorption to formation. J Clin Invest. (2013) 123:3914-24. doi: 10.1172/JCI69493

158. Rao GM, Morghom LO. Effect of obesity on erythrocyte count and hemoglobin levels in Libyan diabetic patients. Clin Physiol Biochem. (1986) 4:277-80.

159. Mairbaurl H. Red blood cells in sports: effects of exercise and training on oxygen supply by red blood cells. Front Physiol. (2013) 4:332. doi: 10.3389/fphys.2013.00332

160. Collins N, Han SJ, Enamorado M, Link VM, Huang B, Moseman $\mathrm{EA}$, et al. The bone marrow protects and optimizes immunological memory during dietary restriction. Cell. (2019) 178:1088-101 el5. doi: 10.1016/j.cell.2019.07.049

161. Romashkan SV, Das SK, Villareal DT, Ravussin E, Redman LM, Rochon J, et al. Safety of two-year caloric restriction in non-obese healthy individuals. Oncotarget. (2016) 7:19124-33. doi: 10.18632/oncotarget.8093

162. Chan ME, Adler BJ, Green DE, Rubin CT. Bone structure and Bcell populations, crippled by obesity, are partially rescued by brief daily exposure to low-magnitude mechanical signals. FASEB J. (2012) 26:4855-63. doi: 10.1096/fj.12-209841

163. Patel VS, Chan ME, Pagnotti GM, Frechette DM, Rubin J, Rubin CT. Incorporating refractory period in mechanical stimulation mitigates obesityinduced adipose tissue dysfunction in adult mice. Obesity. (2017) 25:174553. doi: 10.1002/oby. 21958

164. Nagareddy PR, Kraakman M, Masters SL, Stirzaker RA, Gorman DJ, Grant RW, et al. Adipose tissue macrophages promote myelopoiesis and monocytosis in obesity. Cell Metab. (2014) 19:821-35. doi: 10.1016/j.cmet.2014.03.029

165. Nagareddy PR, Murphy AJ, Stirzaker RA, Hu Y, Yu S, Miller $\mathrm{RG}$, et al. Hyperglycemia promotes myelopoiesis and impairs 
the resolution of atherosclerosis. Cell Metab. (2013) 17:695-708. doi: 10.1016/j.cmet.2013.04.001

166. Shu L, Beier E, Sheu T, Zhang H, Zuscik MJ, Puzas EJ, et al. High-fat diet causes bone loss in young mice by promoting osteoclastogenesis through alteration of the bone marrow environment. Calcif Tissue Int. (2015) 96:31323. doi: 10.1007/s00223-015-9954-z

167. Gerbaix M, Metz L, Mac-Way F, Lavet C, Guillet C, Walrand S, et al. A well-balanced diet combined or not with exercise induces fat mass loss without any decrease of bone mass despite bone micro-architecture alterations in obese rat. Bone. (2013) 53:382-90. doi: 10.1016/j.bone.2013. 01.006

168. Calixto MC, Lintomen L, Schenka A, Saad MJ, Zanesco A, Antunes E. Obesity enhances eosinophilic inflammation in a murine model of allergic asthma. Br J Pharmacol. (2010) 159:617-25. doi: 10.1111/j.1476-5381.2009.00560.x

169. Bolus WR, Kennedy AJ, Hasty AH. Obesity-induced reduction of adipose eosinophils is reversed with low-calorie dietary intervention. Physiol Rep. (2018) 6:e13919. doi: 10.14814/phy2.13919

170. Schwartz C, Eberle JU, Voehringer D. Basophils in inflammation. Eur J Pharmacol. (2016) 778:90-5. doi: 10.1016/j.ejphar.2015.04.049

171. Howarth PH, Pao GJ, Church MK, Holgate ST. Exercise and isocapnic hyperventilation-induced bronchoconstriction in asthma: relevance of circulating basophils to measurements of plasma histamine. $J$ Allergy Clin Immunol. (1984) 73:391-9. doi: 10.1016/0091-6749(84)9 0414-7

172. Brotfain E, Hadad N, Shapira Y, Avinoah E, Zlotnik A, Raichel L, et al. Neutrophil functions in morbidly obese subjects. Clin Exp Immunol. (2015) 181:156-63. doi: 10.1111/cei.12631

173. Kawanishi N, Niihara H, Mizokami T, Yada K, Suzuki K. Exercise training attenuates neutrophil infiltration and elastase expression in adipose tissue of high-fat-diet-induced obese mice. Physiol Rep. (2015) 3:e12534. doi: $10.14814 /$ phy2.12534

174. Imayama I, Ulrich CM, Alfano CM, Wang C, Xiao L, Wener MH, et a;. Effects of a caloric restriction weight loss diet and exercise on inflammatory biomarkers in overweight/obese postmenopausal women: a randomized controlled trial. Cancer Res. (2012) 72:2314-26. doi: 10.1158/0008-5472.CAN-11-3092

175. Collins AT, Kulvaranon ML, Cutcliffe HC, Utturkar GM, Smith WAR, Spritzer CE, et al. Obesity alters the in vivo mechanical response and biochemical properties of cartilage as measured by MRI. Arthritis Res Ther. (2018) 20:232. doi: 10.1186/s13075-0181727-4

176. Ruiz M, Maumus M, Fonteneau G, Pers YM, Ferreira R, Dagneaux L, et al. TGFbetai is involved in the chondrogenic differentiation of mesenchymal stem cells and is dysregulated in osteoarthritis. Osteoarthritis Cartilage. (2019) 27:493-503. doi: 10.1016/j.joca.2018.11.005

177. Yamaguchi S, Aoyama T, Ito A, Nagai M, Iijima H, Tajino J, et al. The effect of exercise on the early stages of mesenchymal stromal cell-induced cartilage repair in a rat osteochondral defect model. PLoS ONE. (2016) 11:e0151580. doi: 10.1371/journal.pone. 0151580

178. Fontinele RG, Krause Neto W, Gama EF, Brito Mari R, de Souza RR, Conrado A, et al. Caloric restriction minimizes aging effects on the femoral medial condyle. Aging Male. (2017) 20:161-7. doi: 10.1080/13685538.2017.13 01418

179. Watkins BA, Li Y, Lippman HE, Feng S. Modulatory effect of omega-3 polyunsaturated fatty acids on osteoblast function and bone metabolism. Prostaglandins Leukot Essent Fatty Acids. (2003) 68:387-98. doi: 10.1016/S0952-3278(03)00063-2

180. Sun D, Krishnan A, Zaman K, Lawrence R, Bhattacharya A, Fernandes G. Dietary n-3 fatty acids decrease osteoclastogenesis and loss of bone mass in ovariectomized mice. J Bone Miner Res. (2003) 18:1206-16. doi: 10.1359/jbmr.2003.18.7.1206

181. Inzana JA, Kung M, Shu L, Hamada D, Xing LP, Zuscik MJ, et al. Immature mice are more susceptible to the detrimental effects of high fat diet on cancellous bone in the distal femur. Bone. (2013) 57:174-83. doi: 10.1016/j.bone.2013.08.003

182. Scheller EL, Khoury B, Moller KL, Wee NK, Khandaker S, Kozloff $\mathrm{KM}$, et al. Changes in skeletal integrity and marrow adiposity during high-fat diet and after weight loss. Front Endocrinol. (2016) 7:102. doi: 10.3389/fendo.2016.00102

183. Tie G, Messina KE, Yan J, Messina JA, Messina LM. Hypercholesterolemia induces oxidant stress that accelerates the ageing of hematopoietic stem cells. J Am Heart Assoc. (2014) 3:e000241. doi: 10.1161/JAHA.113.000241

184. Luo Y, Chen GL, Hannemann N, Ipseiz N, Kronke G, Bauerle T, et al. Microbiota from obese mice regulate hematopoietic stem cell differentiation by altering the bone niche. Cell Metab. (2015) 22:886-94. doi: 10.1016/j.cmet.2015.08.020

185. Bolus WR, Peterson KR, Hubler MJ, Kennedy AJ, Gruen ML, Hasty AH. Elevating adipose eosinophils in obese mice to physiologically normal levels does not rescue metabolic impairments. Mol Metab. (2018) 8:86-95. doi: 10.1016/j.molmet.2017.12.004

186. Ambrosi TH, Scialdone A, Graja A, Gohlke S, Jank AM, Bocian C, et al. Adipocyte accumulation in the bone marrow during obesity and aging impairs stem cell-based hematopoietic and bone regeneration. Cell Stem Cell. (2017) 20:771-84 e6. doi: 10.1016/j.stem.2017.02.009

187. Cortez M, Carmo LS, Rogero MM, Borelli P, Fock RA. A high-fat diet increases IL-1, IL-6, and TNF-alpha production by increasing NF-kappaB and attenuating PPAR-gamma expression in bone marrow mesenchymal stem cells. Inflammation. (2013) 36:379-86. doi: 10.1007/s10753-012-9557-z

188. Tencerova M, Frost M, Figeac F, Nielsen TK, Ali D, Lauterlein JL, et al. Obesity-associated hypermetabolism and accelerated senescence of bone marrow stromal stem cells suggest a potential mechanism for bone fragility. Cell Rep. (2019) 27:2050-62 e6. doi: 10.1016/j.celrep.2019.04.066

189. Xu F, Du Y, Hang S, Chen A, Guo F, Xu T. Adipocytes regulate the bone marrow microenvironment in a mouse model of obesity. Mol Med Rep. (2013) 8:823-8. doi: 10.3892/mmr.2013.1572

190. Wu D, Ren Z, Pae M, Guo W, Cui X, Merrill AH, et al. Aging up-regulates expression of inflammatory mediators in mouse adipose tissue. J Immunol. (2007) 179:4829-39. doi: 10.4049/jimmunol.179.7.4829

191. Naranjo MC, Garcia I, Bermudez B, Lopez S, Cardelo MP, Abia R, et al. Acute effects of dietary fatty acids on osteclastogenesis via RANKL/RANK/OPG system. Mol Nutr Food Res. (2016) 60:2505-13. doi: 10.1002/mnfr.2016 00303

192. Cao JJ, Gregoire BR, Michelsen KG, Picklo MJ. Increasing dietary fish oil reduces adiposity and mitigates bone deterioration in growing C57BL/6 mice fed a high-fat diet. J Nutr. (2019) 150:99-107. doi: 10.1093/jn/ nxz215

193. Styner M, Pagnotti GM, McGrath C, Wu X, Sen B, Uzer G, et al. Exercise decreases marrow adipose tissue through ss-oxidation in obese running mice. J Bone Miner Res. (2017) 32:1692-702. doi: 10.1002/jbmr.3159

194. Krishnamoorthy D, Frechette DM, Adler BJ, Green DE, Chan ME, Rubin CT. Marrow adipogenesis and bone loss that parallels estrogen deficiency is slowed by low-intensity mechanical signals. Osteoporos Int. (2016) 27:74756. doi: 10.1007/s00198-015-3289-5

195. Baker JM, De Lisio M, Parise G. Endurance exercise training promotes medullary hematopoiesis. FASEB J. (2011) 25:4348-57. doi: 10.1096/fj.11-189043

196. De Lisio M, Parise G. Characterization of the effects of exercise training on hematopoietic stem cell quantity and function. J Appl Physiol. (2012) 113:1576-84. doi: 10.1152/japplphysiol.00717.2012

197. Bonsignore MR, Morici G, Santoro A, Pagano M, Cascio L, Bonanno A, et al. Circulating hematopoietic progenitor cells in runners. J Appl Physiol. (2002) 93:1691-7. doi: 10.1152/japplphysiol.0037 6.2002

198. Devlin MJ, Cloutier AM, Thomas NA, Panus DA, Lotinun S, Pinz I, et al. Caloric restriction leads to high marrow adiposity and low bone mass in growing mice. J Bone Miner Res. (2010) 25:2078-88. doi: 10.1002/ jbmr.82

199. Cawthorn WP, Scheller EL, Parlee SD, Pham HA, Learman BS, Redshaw $\mathrm{CM}$, et al. Expansion of bone marrow adipose tissue during caloric restriction is associated with increased circulating glucocorticoids and not with hypoleptinemia. Endocrinology. (2016) 157:508-21. doi: 10.1210/en.2015-1477

200. Bredella MA, Fazeli PK, Miller KK, Misra M, Torriani M, Thomas BJ, et al. Increased bone marrow fat in anorexia nervosa. J Clin Endocrinol Metab. (2009) 94:2129-36. doi: 10.1210/jc.2008-2532 
201. Han J, Luo T, Gu Y, Li G, Jia W, Luo M. Cathepsin K regulates adipocyte differentiation: possible involvement of type I collagen degradation. Endocr J. (2009) 56:55-63. doi: 10.1507/endocrj.K0 $8 \mathrm{E}-143$

202. Stohn JP, Wang Q, Siviski ME, Kennedy K, Jin YR, Kacer D, et al. Cthrc1 controls adipose tissue formation, body composition, and physical activity. Obesity. (2015) 23:1633-42. doi: 10.1002/oby.21144

203. Takeshita S, Fumoto T, Naoe Y, Ikeda K. Age-related marrow adipogenesis is linked to increased expression of RANKL. J Biol Chem. (2014) 289:16699710. doi: $10.1074 /$ jbc.M114.547919
Conflict of Interest: The authors declare that the research was conducted in the absence of any commercial or financial relationships that could be construed as a potential conflict of interest.

Copyright (c) 2020 Benova and Tencerova. This is an open-access article distributed under the terms of the Creative Commons Attribution License (CC BY). The use, distribution or reproduction in other forums is permitted, provided the original author(s) and the copyright owner(s) are credited and that the original publication in this journal is cited, in accordance with accepted academic practice. No use, distribution or reproduction is permitted which does not comply with these terms. 